\title{
A new species of Danielssenia Boeck, 1873 (Copepoda: Harpacticoida: Pseudotachidiidae) from the Arctic shelf and redescription of Danielssenia similis Chislenko, 1978
}

\author{
Новый виА Danielssenia Boeck, 1873 (Copepoda: Harpacticoida: \\ Pseudotachidiidae) с арктического шельфа и переописание \\ Danielssenia similis Chislenko, 1978
}

\author{
L.A. Garlitska ${ }^{1}$, E.S. Chertoprud ${ }^{2,3}$

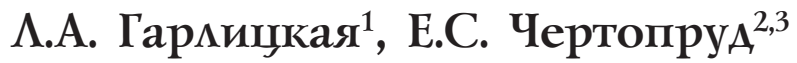 \\ ${ }^{1}$ P.P. Shirshov Institute of Oceanology RAS, Nakhimovsky prospekt, 36, Moscow 117997 Russia. E-mail: garlitska@gmail.com
${ }^{1}$ Институт океанологии им. П.П. Ширшова РАН, Нахимовский проспект, 36, Москва 117997 Россия.
${ }^{2}$ M.V. Lomonosov Mоscow State University, Leninskie Gory, 1/12, Moscow 119234 Russia.
${ }^{2}$ Московский государственный университет им. M.В. Ломоносова, Ленинские горы, 1/12, Москва 119234 Россия.
${ }^{3}$ А.N. Severtsov Institute of Ecology аnd Evolution, Leninsky prospekt 33, Моscow 119071 Russia.
${ }^{3}$ Институт проблем экологии и эволюции им. А.Н. Северцова РАН, Ленинский проспект, 33, Москва 119071 Россия.
}

KEY WORDS: Copepoda, Harpacticoida, Pseudotachidiidae, Danielsseniinae, Danielssenia.

кЛЮЧЕВЫЕ СЛОВА: Copepoda, Harpacticoida, Pseudotachidiidae, Danielsseniinae, Danielssenia.

ABSTRACT. A new species, Danielssenia spiridonovi sp.n., is described from the Kara and East Siberian Sea. It can be distinguished from the known congeners by the differences in the male's seven-segmented antennule, comparatively larger copulatory pore and genital field pattern in females, and different setal formula. Danielssenia similis Chislenko, 1978 is redescribed based on the type material and a new material from the Sea of Okhotsk. The genus now contains six well defined species. A generic amended diagnosis is proposed to accommodate all the species of the genus, and a key to the species of Danielssenia is presented.

How to cite this paper: Garlitska L.A., Chertoprud E.S. 2021. A new species of Danielssenia Boeck, 1873 (Copepoda: Harpacticoida: Pseudotachidiidae) from the Arctic shelf and redescription of Danielssenia similis Chislenko, 1978 // Arthropoda Selecta. Vol.30. No.3. P.309-330. doi: 10.15298/arthsel.30.3.05

РЕЗЮМЕ. Новый вид, Danielssenia spiridonovi sp.n., описан из Карского и Восточно-Сибирского морей. От уже известных видов рода он отличается 7-сегментной антеннулой самца, сравнительно большой копулятивной порой и рисунку генитального поля у самок, и иной формулой щетинок. Danielssenia similis Chislenko, 1978 переписан на основе нового материала из Охотского моря. Род в настоящее время содержит шесть четко определенных видов. Предлагается исправленный родовой диагноз, которому удовлетворяли бы все виды рода, а также представлен ключ для рода Danielssenia.
Introduction

Throughout its taxonomic history the genus Danielssenia Boeck, 1873 has been transferred across several families and "has served as a repository to accommodate different kinds of 'tachidiid' harpacticoid copepods" [Huys, Gee, 1993: 46]. In a series of papers [Gee, Huys, 1990, 1991, 1994; Huys, Gee, 1992, 1993, 1996] the pre-1980s concept of the genera has been challenged. Based on the structure of the mouthparts and sexual dimorphism of the swimming legs, Huys and Gee outlined the phylogenetic relationships within the group, resulting in the creation of a number of new genera. Most of species previously attributed to the genus were synonymized and/or allocated to these "danielsseniid" genera in the subfamily Paranannopinae Por, 1986. Later, Huys et al. [1996] introduced the new family name Danielsseniidae to replace Paranannopidae and accordingly renamed the subfamily to Danielsseniinae Huys et Gee, 1996; while Willen [2000] transferred the subfamily (under the old name) to Pseudotachidiidae. At present, Danielsseniinae is considered as a subfamily in Pseudotachidiidae, with Danielssenia fixed as its type taxon.

After the Huys \& Gee's [1993] revision, only four Danielssenia species remained in the genus: $D$. typica Boeck, 1873, D. quadriseta Gee, 1988, D. reducta Gee, 1988, and D. similis Chislenko, 1978, the latter degraded to taxon inquirendum. Later, Gee \& Huys [1994] described D. spitsbergensis Gee et Huys, 1994 as incertae sedis within Danielssenia pending the discovery of the female. The composition of the genus has not change since. Recently, Garlitska \& Chertoprud 


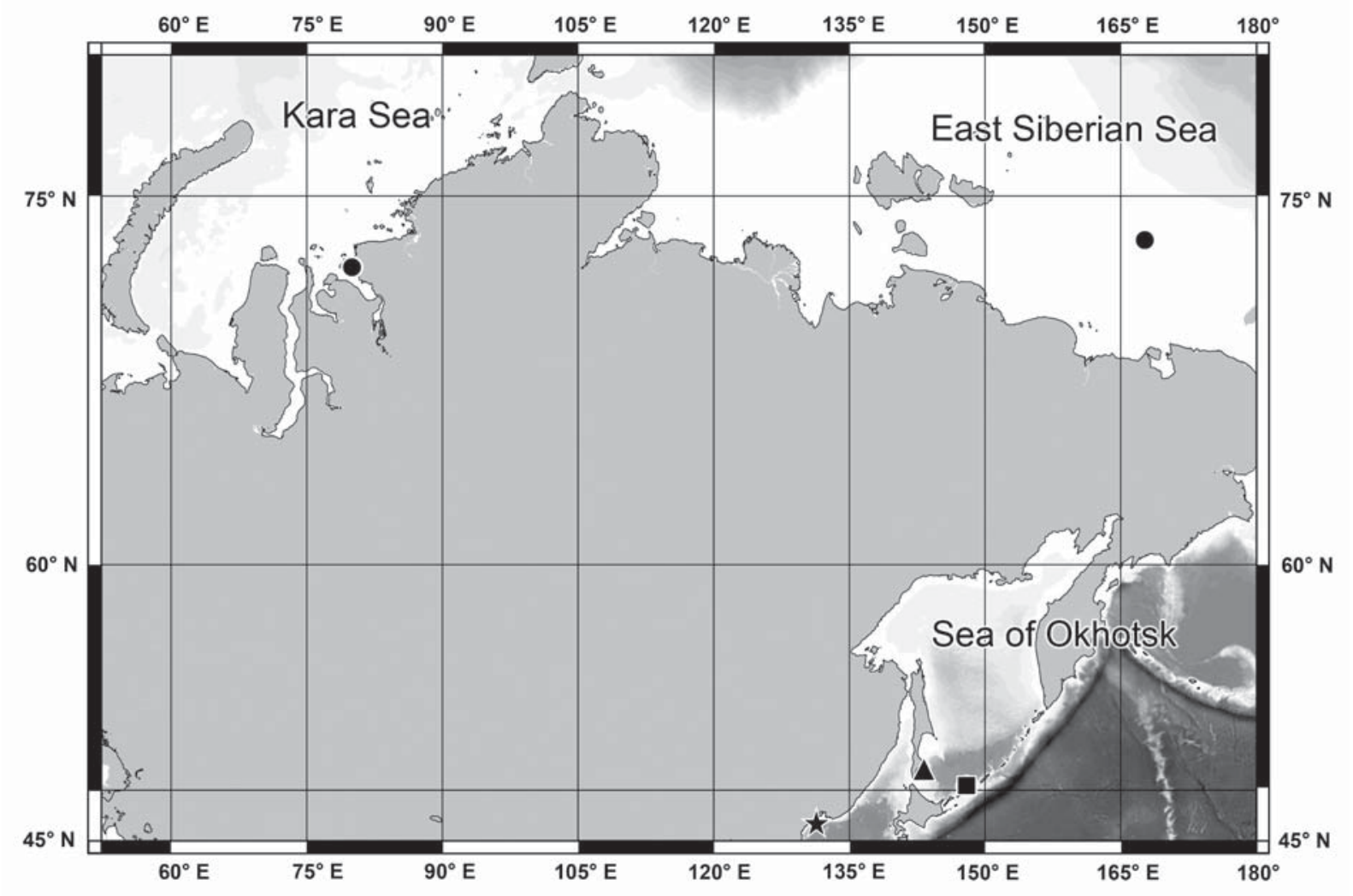

Fig. 1. Distribution of Danielssenia spesies: $-D$. spiridonovi sp.n., $\star-D$. similis ([Chislenko, 1978], type locality), $\mathbf{\square}-D$. similis (own data), $\boldsymbol{\Delta}$ - D. similis ([Zavarzin, Atamanova, 2014]).

Рис. 1. Распространение видов Danielssenia: — D. spiridonovi sp.n., „ - D. similis ([Chislenko, 1978], типовое местообитание), $\boldsymbol{\square}-D$. similis (собственные данные), $\boldsymbol{\Delta}-D$. similis ([Zavarzin, Atamanova, 2014]).

[2021, in press] described the females of D. spitsbergensis from the Kara Sea but did not take the species out of its incertae sedis status, because some distinctive features of the specimens disagreed with the current generic diagnosis.

Several danielsseniid harpacticoids were discovered during the course of a study on the harpacticoid fauna from the Kara Sea, East Siberian Sea, and the Sea of Okhotsk. In this paper, we described one new species from the Kara Sea and East Siberian Sea. Additionally, we present a re-description of $D$. similis and give some comments on the reassessment of its taxonomic status.

\section{Material and methods}

The material was collected from different sites at the eastern Kara Sea (September-October 2011), the East Siberian Sea (September 2019), and the Sea of Okhotsk (June 2013) (Fig. 1). In the former two cases, sediments were collected using a multicorer or by a Niemistö gravity corer; in the Sea of Okhotsk, water column from bottom to surface was sampled at upper subtidal zone (depths $10-50 \mathrm{~m}$ ) by plankton net. The upper $5 \mathrm{~cm}$-layer of each sediment samples was retrieved for meiofauna analyses using a plastic core of $2 \mathrm{~cm}$ in inner diameter. The samples were fixed on board with a $5 \%$ formalin solution and subsequently washed in the laboratory with tap water. The meiofauna was extracted from sediments by centrifugation using Levasil CS40316 LSP as a flotation medium and kaolin to cover the sand particles. The samples were centrifuged three times at 4,000 rpm for five minutes. After centrifugation, the upper fraction containing the meiobenthic organisms was sieved using a mesh size of $40 \mu \mathrm{m}$, washed with fresh water and stained with Rose Bengal. The copepods were picked out and sorted under a stereomicroscope Leica MZ APO.

The habitus was photographed and body length measurements were made from whole specimens mounted in glycerin. Harpacticoids were dissected in glycerin and the parts were mounted individually in lactophenol and the slides were sealed with transparent nail varnish. Observations were made with a Leica MZ APO and Olympus CX41. Identification to species level was done with the tabular keys by Wells [2007] and identifications were checked with the original literature. All drawings were made with a drawing tube attached to the Olympus CX41 light microscope. Morphological terminology follows Huys \& Boxshall [1991]. Abbreviations used in the text and figure legends: A1 - antennule, A2 - antenna, md: mandible, mxl - maxillule, $\mathrm{mx}$ maxilla, mxp - maxilliped, GDS - genital double somite, CR - caudal ramus, P1-P6 - swimming legs 1-6, enp endopodite, exp - exopodite, enp-1 - first segment of enp, benp - basendopodite. All material was deposited in the Shirshov Institute of Oceanology, Russian Academy of Science and the Zoological Museum of the Lomonosov Moscow State University. 
In addition to the two species described below, several specimens of Danielssenia typica Boeek, 1872, D. quadriseta Gee 1988, and D. spitsbergensis Gee et Huys, 1994 from the Kara Sea material have also been examined for the comparison.

\section{Taxonomy}

Order Harpacticoida Sars, 1903

Family Pseudotachidiidae Lang, 1936

Subfamily Danielsseniinae Huys et Gee in Huys et al., 1996

Genus Danielssenia Boeck, 1873

TYPE SPECIES. D. typica Boeck, 1873

OTHER SPECIES. D. quadriseta Gee, 1988, D. reducta

Gee, 1988, D. spitsbergensis Gee et Huys, 1994

SPECIES INQUIRENDAE. D. similis Chislenko, 1978

\section{Danielssenia spiridonovi sp.n.}

Figs 2-9.

Danielssenia sp.: Garlitska, Azovsky, 2016

TYPE LOCALITY. The East Siberian Sea $\left(73^{\circ} 41^{\prime} \mathrm{N}\right.$ $167^{\circ} 40^{\prime} \mathrm{W}$ ), depth $40 \mathrm{~m}$, mud.

TYPE MATERIAL. The Zoological Museum of the Lomonosov Moscow State University, Moscow, Russia: holotype, 1 q dissected on 4 slides (reg. no. Me-1219); allotype, $1 \mathrm{O}^{\text {T }}$ partly dissected on 1 slide (reg. no. Me-1220); P.P. Shirshov Institute of Oceanology, Russian Academy of Science, Moscow: paratype, 1 dissected on 4 slides (reg. no. IORAS-Har216-219); paratype, 10 dissected on 4 slides (reg. no. IORAS-Har220-223); all from meiofauna samples collected at type locality; coll. L. Garlitska, September 2019.

OTHER MATERIAL. The eastern Kara Sea $\left(72^{\circ} 49^{\prime} \mathrm{N}, 80^{\circ} 00\right.$ E), depth 20-53 m, mud; 12 ㅇ (5 dissected by LG) and 3 O $^{7} \sigma^{7}$ (2 dissected by LG); all from meiofauna samples; coll. A.A. Udalov, September-October 2011.

DESCRIPTION (based on type material). FEMALE. Body (Fig. 2A-C). Length from base of rostrum to end of last somite $0.80 \mathrm{~mm}$. Body fusiform in shape with widest part at first three thoracic segments with clear distinction between prosome and urosome. Rostrum (Fig. 3A) large $0.06 \mathrm{~mm}$, semi-hyaline, slightly recurved downwards anteriorly, with two pairs of minute sensillum. Lateral epimeral plates of almost all segments with row of spinules on posterior margin dorsally and ventrally. Abdomen ornamented as in Fig. 2B, C. Genital and third urosomite fused forming GDS. Genital field (Fig. 2D) with comparatively large copulatory pore, and paired seminal receptacles. Vestigal P6 with one pinnate seta and one spinule. Terminal segment deeply divided; semi-operculum inconspicuous. CR (Fig. 2A-C, E) 1.3 times as long as board. Pattern of CR setation as in Fig. 2E. Ventral posterior margin of $\mathrm{CR}$ bearing row of stout spinules.

A1 (Fig. 2A-C). Short, stout, 4-segmented. First segment the largest with tree rows of spinules on dorsal surface and a pinnate seta at distal corner. Second segment almost rectangular with nine setae, the longest of which is located subdistally on the inner margin of the segment; the other two setae are situated subdistally close to the outer margin. Aesthetasc and twelve setae on third segment (Fig. 3B). Nine setae, five setules and small free aesthetasc (acrotek) on distal segment (Fig. 3C). Armature formula, 1-(1), 2-(9), 3$(12+a e), 4-(9+5+a e)$.
A2 (Fig. 3D). Allobasis with a spinulose abexopodal seta with row of spinules at the base. Exp 3-segmented with spinulose setae on first two segments, and three spinulose setae on distal one. Free endopodal segment with one proximal and subdistal rows of long spinules, two spinulose and one geniculate seta situated medially, and four geniculate and one spinulose setae located on distal margin. One small seta is fused basally to the distal outer element.

Labrum (Fig. 4E). Ornamented as in the figure.

$M d$ (Fig. 4C, D). Coxa robust, gnathobase with welldeveloped blunt teeth and a single pinnate seta at distal corner. Basis with three large plumose distal setae and row of spinules medially. Exp 1-segmented with two plumose distal and one spinulose medial seta. Enp 1-segmented with row of spinules and two setae on inner margin and six setae on distal margin.

$M x l$ (Fig. 4A). Praecoxal arthrite with nine spines, one spinulose seta on distal margin and two tubular setae on anterior surface, and one row of spinules on posterior surface; coxal endite with two pinnate setae, one setulose claw and three tubular setae; basis with three pinnate and three tubular setae. Exp and enp 1-segmented each with three pinnate setae.

$M x$ (Fig. 4B). Syncoxa with three endites: proximal with two spinulose clows, medial with three clows (one of them spinulose), distal endite with three bare elements. Allobasis with two claws (one of them visibly stronger) and two setae (one anterior, one posterior). Enp 1-segmented with two setae and one spine.

Mxp (Fig. 4E). Syncoxa with two rows of spinules on inner margin proximally and distally; one long plumose seta situated medially and one distal smaller plumose seta inserted subdiatantlly. Basis long with row of spinules on inner margin and small pinnate seta. Terminal claw a little longer than basis with accessory seta near base.

P1 (Fig. 5A). Intercoxal sclerite rectangular with two rows of spinules on distal margin. Coxa with one row of large spinules at distal outer corner and two rows of spinules centrally on anterior surface. Basis with an outer and an inner plumose seta and with row of long spinules centrally on distal margin. Exp 3-segmented, each segment with a row of spinules along distal and outer margins; exp-1 with one outer spine, exp-2 with one outer spine and one inner setae, exp-3 with five setae (three outer spines and two distal setae). Enp 2-segmented, longer than exp; enp-2 more than twice as long as enp-1, both segments with rows of spinules along distal and outer margins; enp-1 with one inner seta situated medial, enp-2 with four elements (one inner seta, two distal, one outer distal spine).

$P 2$ (Fig. 5B). Intercoxal sclerite rectangular with two rows of spinules on distal margin. Coxa almost rectangular with four groups of spinules: long at outer margin, proximal outer corner and distal interior corner; and row of small spinules at distal exterior margin. Basis with an outer plumose spine and with row of long spinules medially on distal margin. Exp 3-segmented, each segment with a row of spinules along outer margin; exp-1 with one outer spine, exp-2 with one outer spine and one inner seta, exp-3 with six elements (three outer spines, two distal and one inner setae). Enp 3-segmented, longer than exopodite, enp-1 and enp-2 with row of spinules at outer margin and each with one inner setae, enp-3 with five elements (two inner and two distal setae, and one outer distal spine).

P3 (Fig. 6A). Intercoxal sclerite rectangular with two rows of spinules on distal margin. Coxa with three outer 

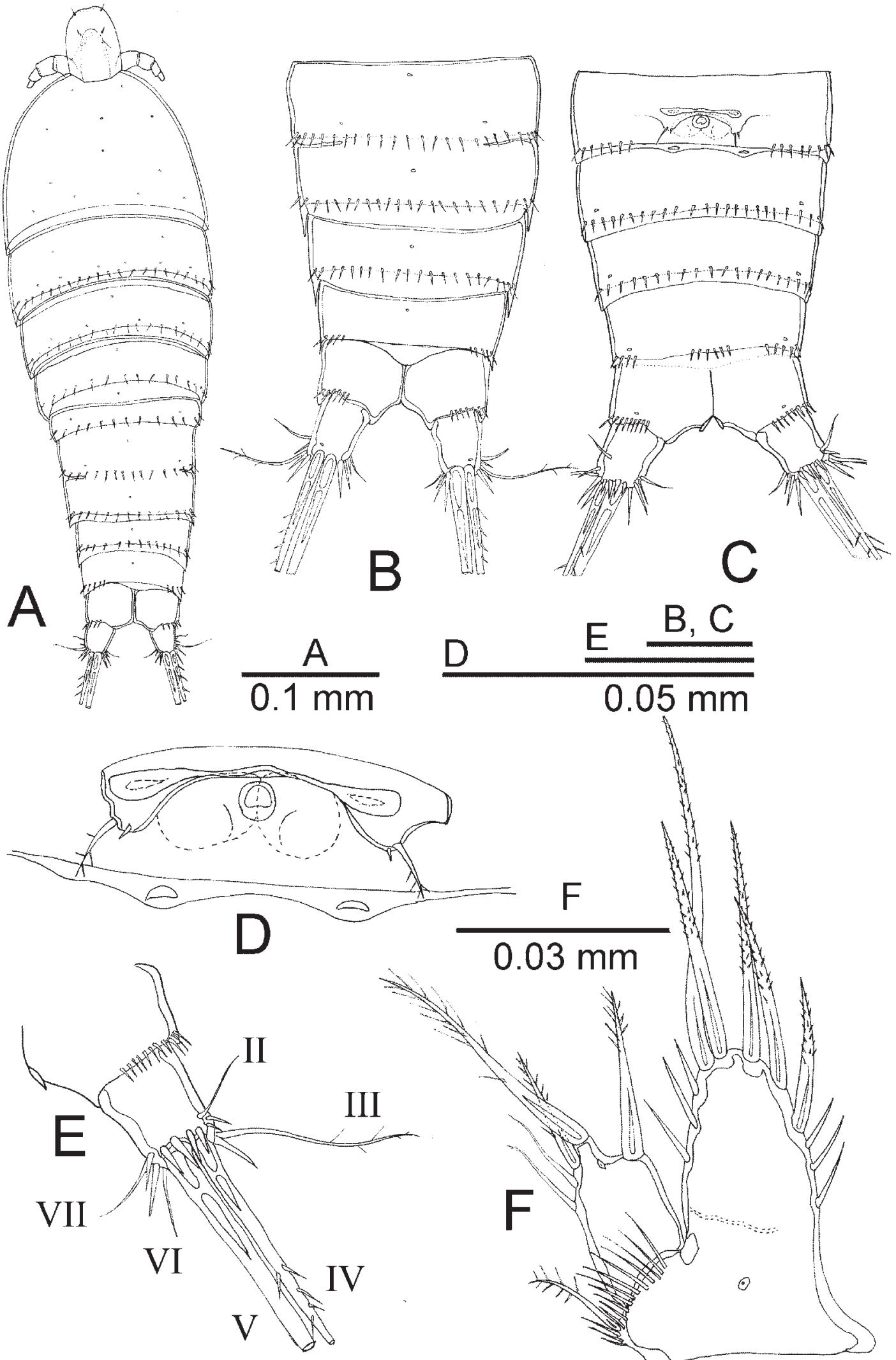

Fig. 2. Danielssenia spiridonovi sp.n., female. A — body in dorsal view; B — abdomen in dorsal view; C - abdomen in ventral view; $\mathrm{D}$ - genital field; E - left CR in ventral view; F - P5.

Рис. 2. Danielssenia spiridonovi sp.n., самка. А - туловище, вид сзади; В - абдомен, вид сзади; С - абдомен, вид спереди; D генитальное поле; Е — левая фуркальная ветвь, вид спереди; F — 5-я нога. 


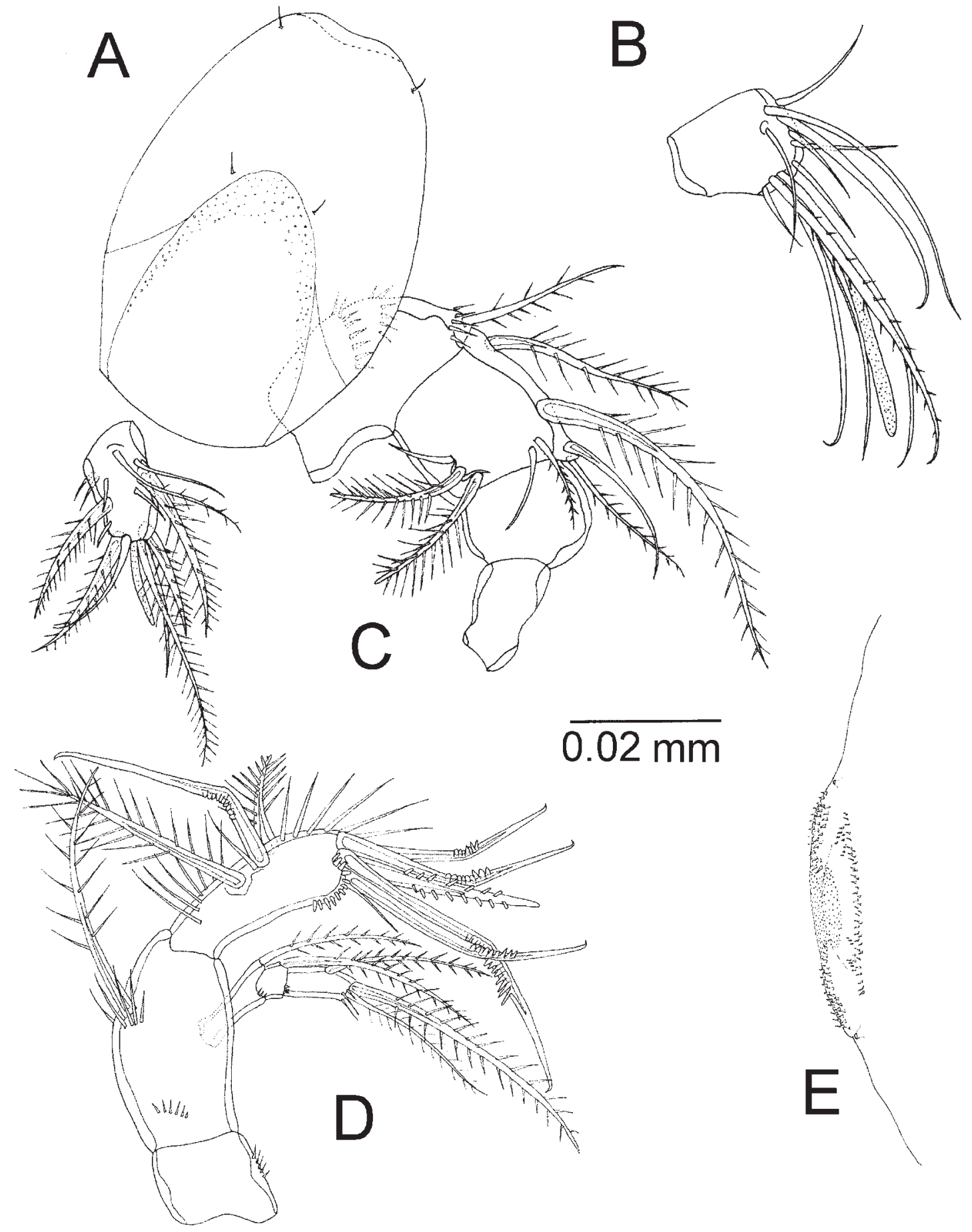

Fig. 3. Danielssenia spiridonovi sp.n., female. A - rostrum and A1; B - 3th segment of A1; C - 4th segment of A1; D - A2; E labrum.

Pис. 3. Danielssenia spiridonovi sp.n., самка. А - рострум и антеннула; В - 3-й сегмент антеннулы; С - 4-й сегмент антеннулы; D — антенна; Е — лябрум.

spinular rows at distal outer margin, proximal distal corner and inner distal margin. Basis with an outer plumose seta, one row of spinules at outer margin, and one row of spinules at medial proximal margin. Exp and enp 3-segmented each with row of outer spinules. Exp-1 with outer spine, exp-2 with one outer spine and one inner setae, exp-3 with six elements (three outer spines, two distal and one inner setae). Enp-1 and enp-2 each with one inner seta, enp-3 with five elements (one outer spine, two distal and two inner setae).

P4 (Fig. 6B). Intercoxal sclerite rectangular. Coxa with two spinular rows at proximal and outer distal margin. Basis 

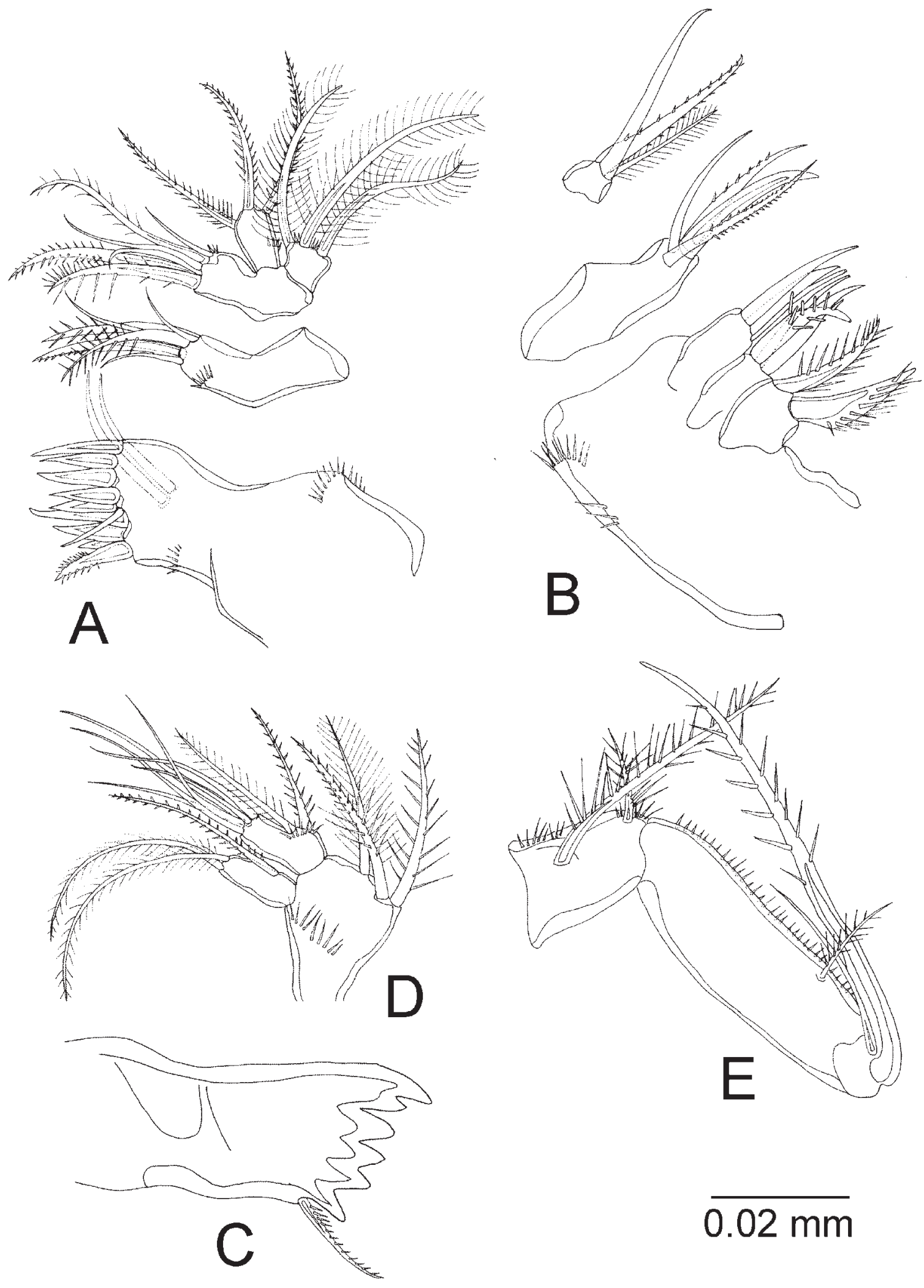

$\overline{0.02 \mathrm{~mm}}$

Fig. 4. Danielssenia spiridonovi sp.n., female. A - mxl; B - mx; C - md gnathobase; D - md palp; E - mxp.

Рис. 4. Danielssenia spiridonovi sp.n., самка. А - максиллула; В — максилла; С — гнатобаза мандибулы; D — пальпа мандибулы; Е - максилипед. 


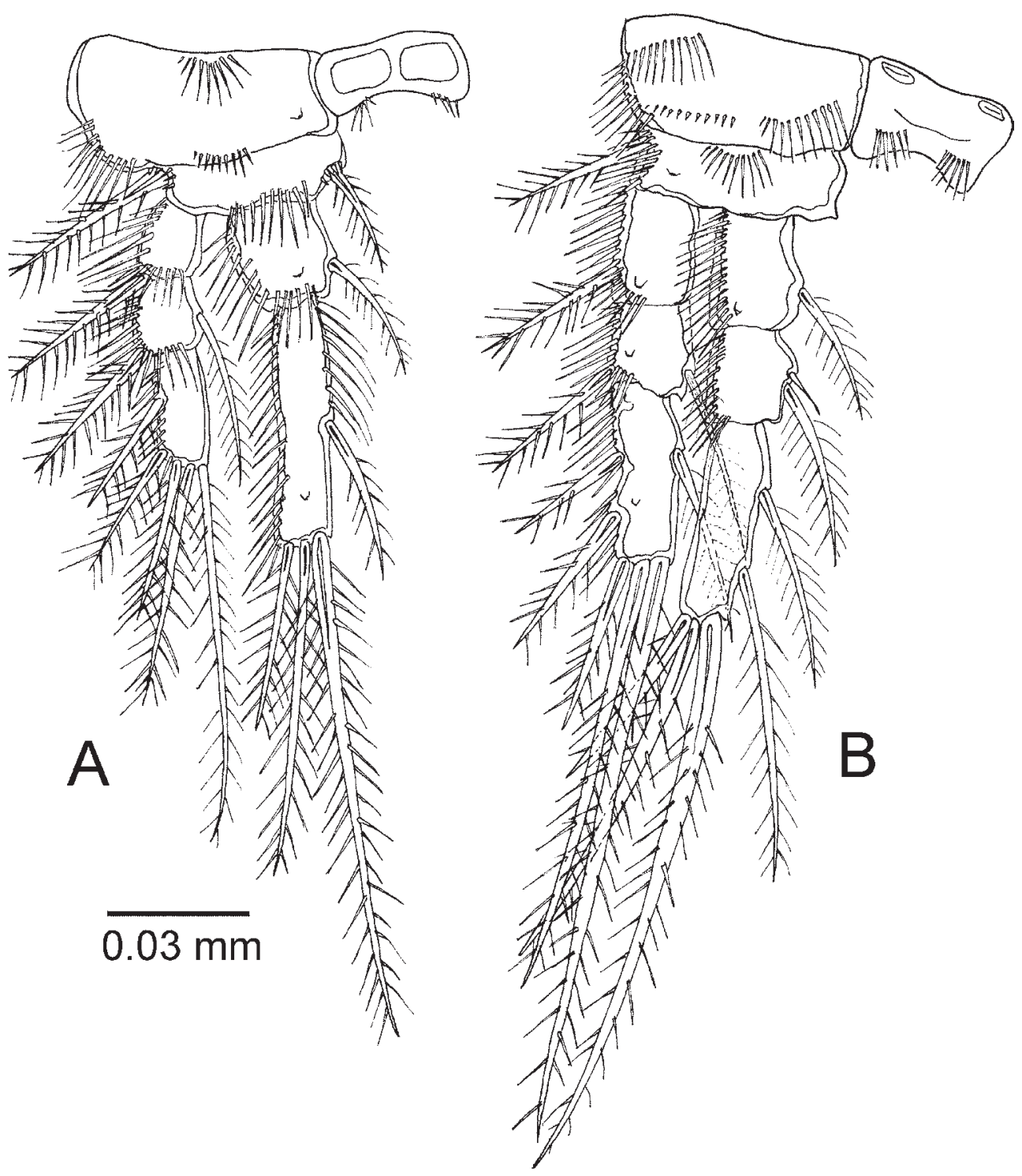

Fig. 5. Danielssenia spiridonovi sp.n., female. A - P1; B - P2.

Рис. 5. Danielssenia spiridonovi sp.n., самка. А - 1-я нога; В - 2-я нога.

comparatively narrow with an outer plumose spine and outer row of spinules. Exp and enp 3-segmented each with spinular row at outer margin. Exp-1 with outer spine, exp-2 with one outer spine and one inner setae, exp-3 with six elements (three outer spines, two distal and one inner setae). Enp-1 and enp-2 each with one inner setae, enp-3 with three elements (one outer spine and two distal setae).

Setal formula of swimming legs as follows:

$\begin{array}{lcc} & \text { Exp } & \text { Enp } \\ \text { P1 } & 0: 1: 023 & 1: 121 \\ \text { P2 } & 0: 1: 123 & 1: 1: 221 \\ \text { P3 } & 0: 1: 123 & 1: 1: 221 \\ \text { P4 } & 0: 1: 123 & 1: 1: 021\end{array}$

P5 (Fig. 2F). Benp and exp distinct. Benp with a row of strong spinules around base of outer basal seta, close to joint of exopodite, and three strong single spinules on inner and outer margin, and armed with five strong spinulose setae of which outermost longest. Exp a little longer than board with five setae; middle seta the longest with plumose tip.
MALE. Body (Fig. 7A-C). Length from base of rostrum to end of last segment $0.71 \mathrm{~mm}$. Rostrum length $0.05 \mathrm{~mm}$ Body shape and ornamentation as in female. Genital segment and third urosomite not fused. Ornamentation as in Fig. 7A-C.

A1 (Fig. 8). Subchirocer, 7-segmented. Segment-1 with two rows of spinules and a spinulose seta is situated subdistally on inner margin. Segment-2 short with one spinulose seta at distal inner corner. Segment-3 (Fig. 8A, B) with ten setae situated on distal margin seven of which spinulose. Segment-4 short, almost triangular with eight setae. Segment-5 expanded and bearing ten setae plus one seta fused basally to one aesthetasc. Last two segments forming prehensile claw with three and five setae on them. Segment-7 with small free aesthetasc. Armature formula, 1-(1), 2-(1), 3-(10), 4-(8), 5-(10+[1+ae]), 6-(3), 7-(5+ae).

A2, labrum and mouthparts. Not shown, as in female.

$P 1$. Not shown as in female.

P2 (Fig. 9A). Exp as in female, enp modified. Enp-1 with row of spinules on outer border and a plumose inner 


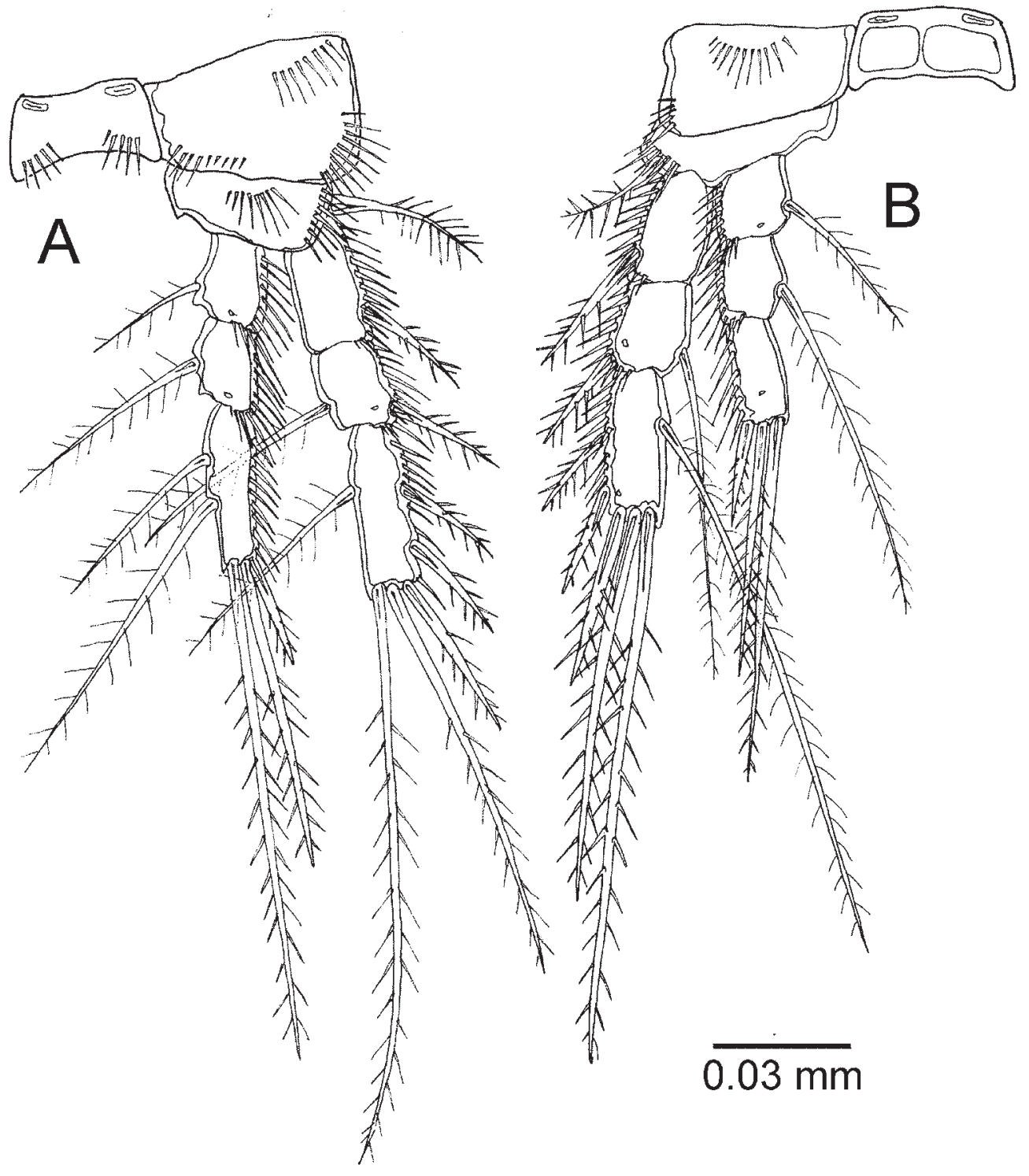

Fig. 6. Danielssenia spiridonovi sp.n., female. A - P3; B - P4.

Рис. 6. Danielssenia spiridonovi sp.n., самка. А - 3-я нога; В - 4-я нога.

seta. Enp-2 with a mucroniform process at outer distal corner about 4.5 times as long as basal portion of segment, and with an inner seta. Enp-3 with four rows of spinules (two medial and two distal), two large inner plumose setae, one short plumose subdistal seta, and one short bent distal seta.

P3 (Fig. 9B). As in female, except enp-2 with small recurved process at outer distal corner.

$P 4$. Not shown as in female.

P5 (Fig. 7D). Exp and benp separate, benp of both legs fused medially. Benp with row of outer spinules and with plumose outer seta. Endopodal lobe reduced, bearing two setae of different lengths. Exp with row of strong spinules on distal outer margin and five setae (with wide gap between innermost and neighboring seta).

P6 (Fig. 7E). A single plate fused to somite; each leg bearing two setae and several strong spines on each side.

ETYMOLOGY. This species is named in honour of V.A. Spiridonov of the P.P. Shirshov Institute of Oceanology Russian Academy of Science, who was a well-known
Russian carcinologist, our colleague and friend. It is a noun in the genitive case.

REMARKS. A few specimens of D. spiridonovi sp.n. were first found at several stations in the southern Kara Sea, on sandy silts and silts, at depths of $20-53 \mathrm{~m}$ and nearbottom salinity 31-33. Garlitska \& Azovsky [2016] referred to this species as Danielssenia sp. In the East Siberian Sea, this species was found so far at a single station (depth $40 \mathrm{~m}$; silt) collected during the ARA10C cruise on IRV "Araon" (Korea) in September, 2019. Its distribution can preliminarily be considered as high-Arctic at the upper continental shelf.

This species is more closely related to $D$. reducta, but these two species are clearly differentiated on the basis of the following characters: i) number of sensillae on the rostrum (two pairs in D. spiridonovi sp.n. but one pair in $D$. reducta); ii) differences in the structure of the genital field; iii) length of the caudal rami (shorter in D. spiridonovi sp.n.); iv) setae arrangement on the antennal enp; v) mandibular 


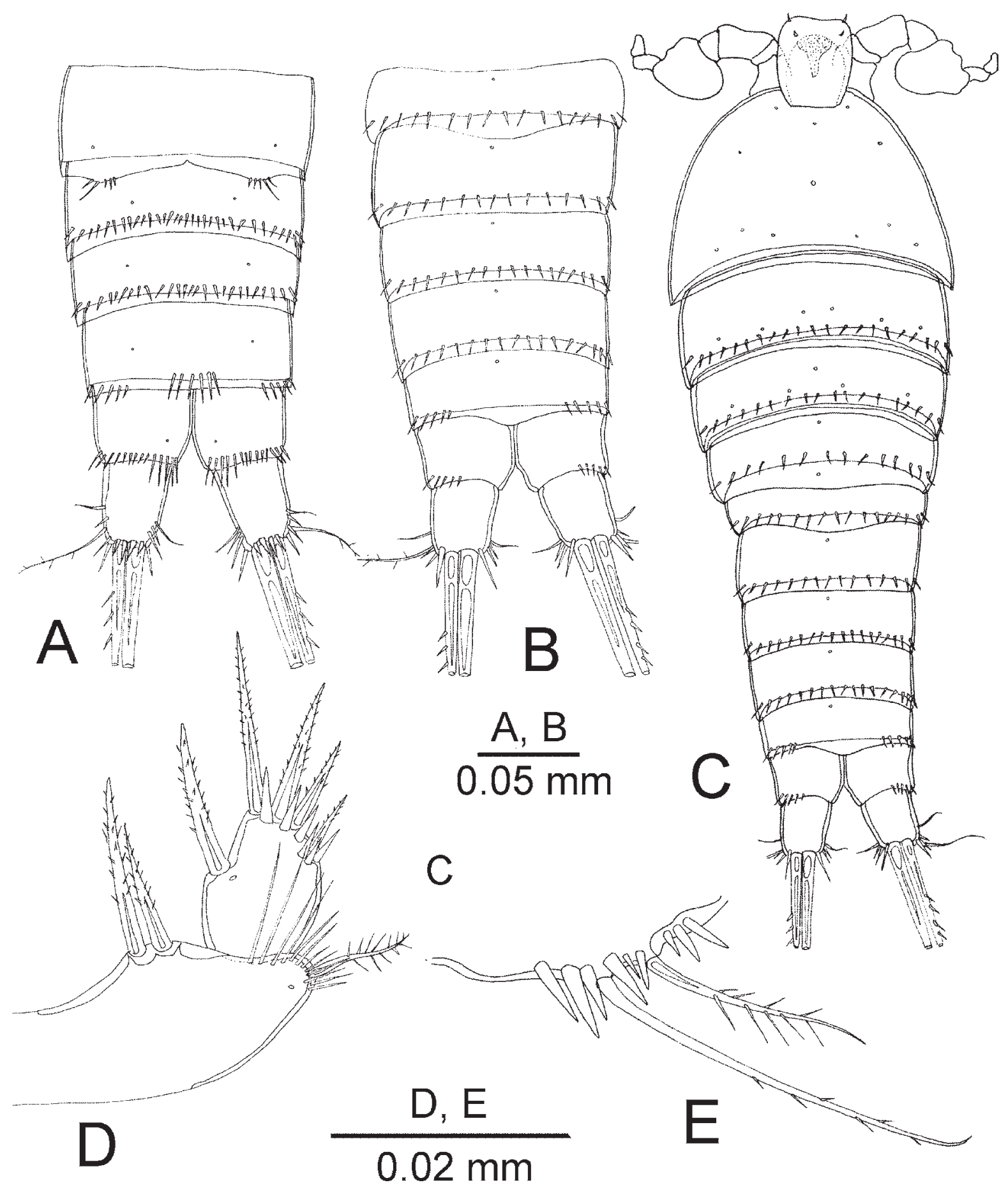

Fig. 7. Danielssenia spiridonovi sp.n., male. A — abdomen in ventral view; B - abdomen in dorsal view; C — body in dorsal view; $\mathrm{D}-\mathrm{P} 5 ; \mathrm{E}-\mathrm{P} 6$

Рис. 7. Danielssenia spiridonovi sp.n., самец. А - абдомен, вид спереди; В - абдомен, вид сзади; С - туловище, вид сзади; D 5-я нога; Е - 6-я нога.

structure (1-segmented exp with three setae in D. spiridonovi sp.n., but 2 -segmented with a single seta in $D$. reducta); vi) differences in setation of $\mathrm{P} 4$ exp-3 (one inner seta in D. spiridonovi sp.n., but two inner setae in D. reducta); and vii) the second seta on the P5 is pinnate in $D$. spiridonovi sp.n., but unornamented in D. reducta. As a result of finding $D$. spiridonovi sp.n. together with several other congeners at the same sites, and because of the differences discussed above, we have no doubt in according our specimens the status of a new species. 


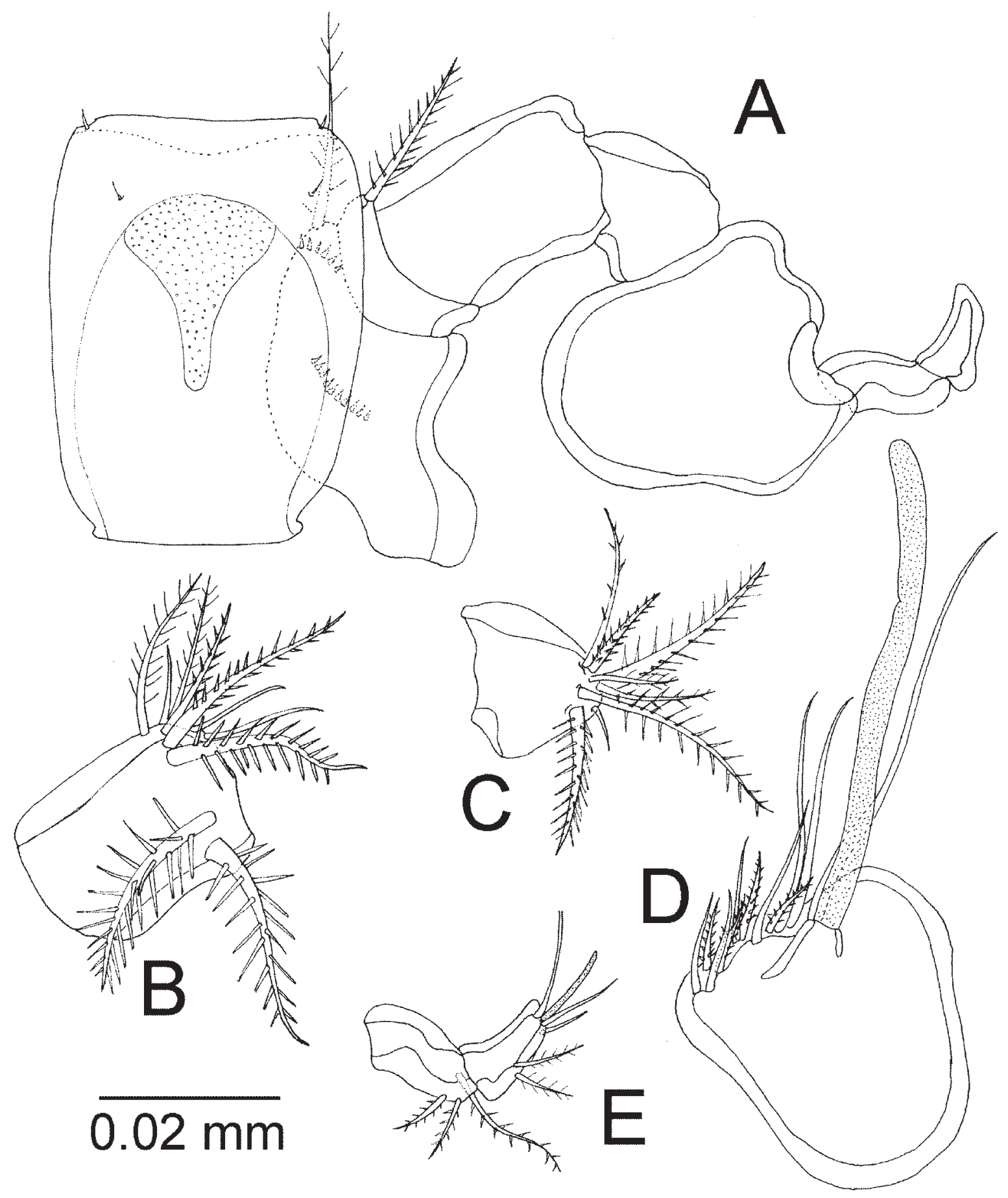

Fig. 8. Danielssenia spiridonovi sp.n., male. A - rostrum and A1; B - 3th segment of A1; C - 4th segment of A1; D - 5th segment of A1; E - 6th and 7th segments of A1.

Pис. 8. Danielssenia spiridonovi sp.n., самец. А - рострум и антеннула; В - 3-й сегмент антеннулы; C - 4-й сегмент антеннулы; D - 5-й сегмент антеннулы; Е - 6-й и 7-й сегменты антеннулы.

Danielssenia similis Chislenko, 1978 stat.n. Figs 10-17.

TYPE LOCALITY. The Posyet Bay, the Sea of Japan, 3-4 m, muddy sand.

TYPE MATERIAL. Holotype: 1 q dissected on 1 slide (reg. no. 12, 14, 61229); paratype: $1 \mathrm{O}^{7}$ dissected on 1 slide (reg. no. 12 , 15,61229 ); collected from the type locality by L.L. Chislenko on April 1965, deposited in the Zoological Institute, Russian Academy of Science, Saint Petersburg, Russia.

OTHER MATERIAL. The Sea of Okhotsk near the Iturup Island $\left(45^{\circ} 19^{\prime} \mathrm{N} 147^{\circ} 59^{\prime} \mathrm{E}\right): 2$ 우 (1 dissected by LG) and $90^{\top} \mathrm{O}^{7}$ ( 2 dissected by LG); collected from planktonic samples, coll. S.E. 

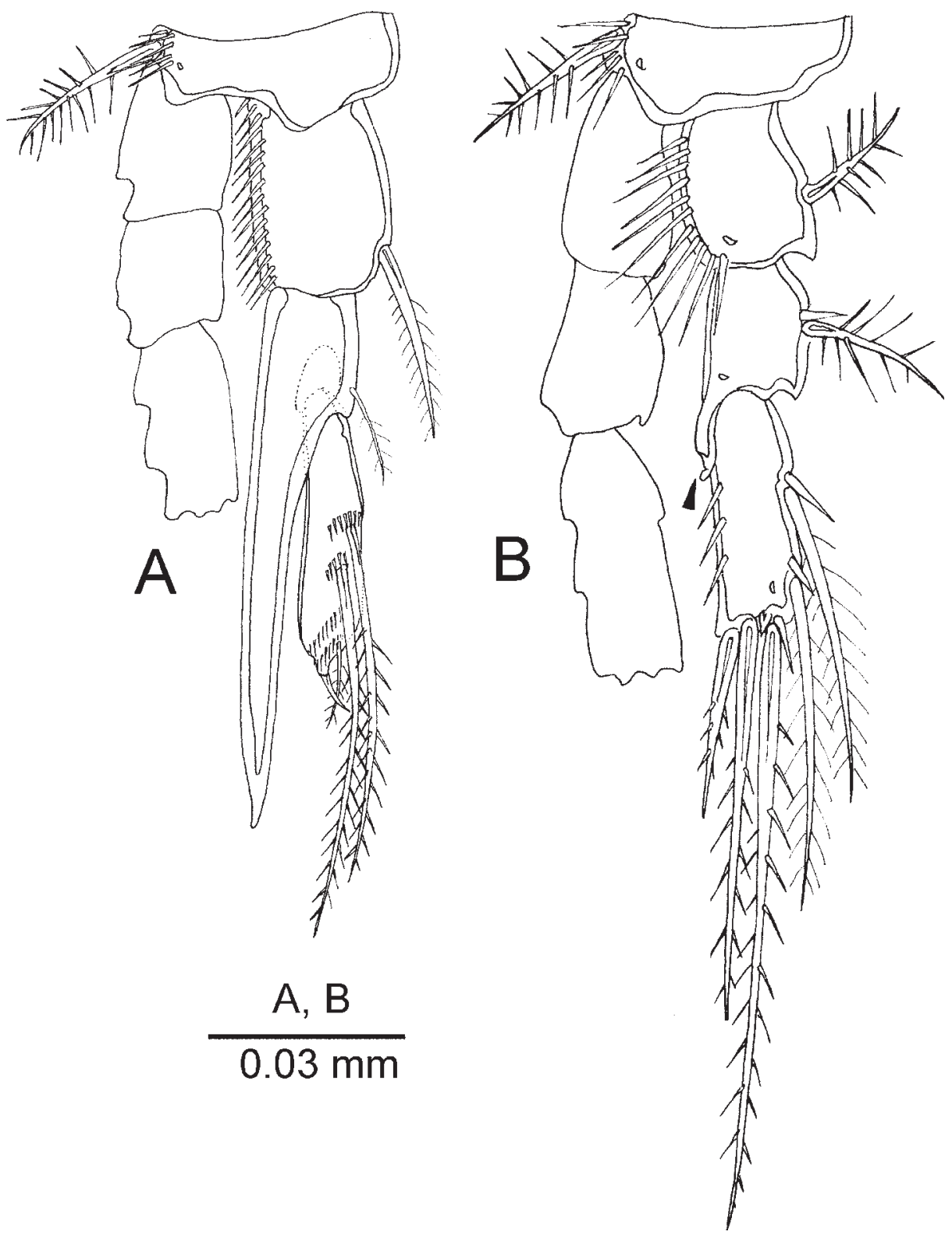

Fig. 9. Danielssenia spiridonovi sp.n., male. A - P2; B - P3.

Рис. 9. Danielssenia spiridonovi sp.n., самец. А - 2-я нога; В - 3-я нога.

Frenkel, June 2013. Slides deposited in the Zoological Museum of the Lomonosov Moscow State University, Moscow, Russia: 1 dissected on 4 slides (reg. no. Me-1221), $1 \sigma^{7}$ dissected on 4 slides (reg. No. Me-1222); and in Shirshov Institute of Oceanology, Russian Academy of Science: 1 whole body + (reg. No. IORAS-Har224), $1 \sigma^{7}$ dissected on 4 slides (reg. No. IORAS-Har225-228).

DESCRIPTION (based on type material and material from the Sea of Okhotsk). FEMALE. Body (Fig. 10A-C). Length from base of rostrum to end of last segment 0.86 $\mathrm{mm}$. Body fusiform with widest part at first three thoracic segments with no clear distinction between prosome and urosome. Somatic hyaline frills of pedigerous and abdominal somites minutely dentate. Rostrum (Fig. 11A) $0.15 \mathrm{~mm}$ large, semi-hyaline, slightly recurved anteriorly, with one pair of minute sensilla. GDS with continuous chitinous rib laterally and ventrally. Genital field (Fig. 10D) with comparatively large copulatory pore, and paired seminal recepta- cles. Female P6 represented by one plumose seta and one spine. Abdomen ornamented as in Fig. 10B, C. Pseudoperculum formed by deeply incised posterior extension of penultimate somite. CR as broad as long, with six setae (Fig. $10 \mathrm{E})$, the first seta is absent.

A1 (Fig. 11A, B). Stout, short, 4-segmented. First segment with plumose seta and two rows of spinules on dorsal surface. Second segment bears eight setae: five setae stout and spinulose, three short and bare. Third segment with three spinulose setae, five short smooth setae and aesthetasc and bundle of free long simple setae. Forth segment (Fig. 11B) with eight spinulose setae and three short and simple elements. Armature formula, 1-(1), 2-(8), 3-(11+ae), 4-(11).

A2 (Fig. 11C). Allobasis bearing a spinulose abexopodal seta with row of spinules at its base. Exp 3-segmented with spinulose setae on first two segments, and three spinulose 

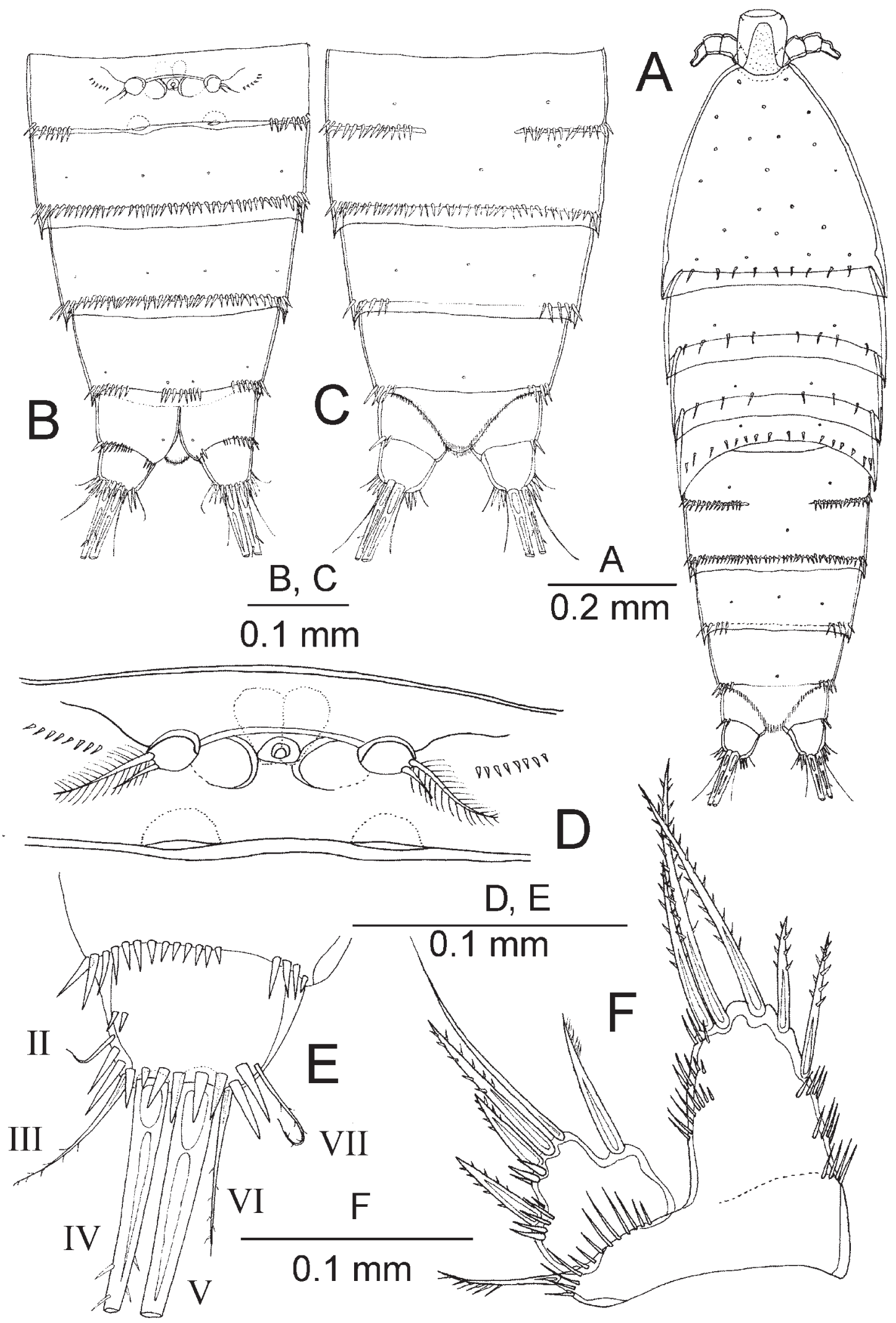

Fig. 10. Danielssenia similis, female. A - body in dorsal view; B - abdomen in ventral view; C - abdomen in dorsal view; D genital field; E - right CR in ventral view; F - P5.

Рис. 10. Danielssenia similis, самка. А - туловище, вид сзади; В - абдомен, вид спереди; С - абдомен, вид сзади; D генитальное поле; Е - правая фуркальная ветвь, вид спереди; F - 5-я нога. 


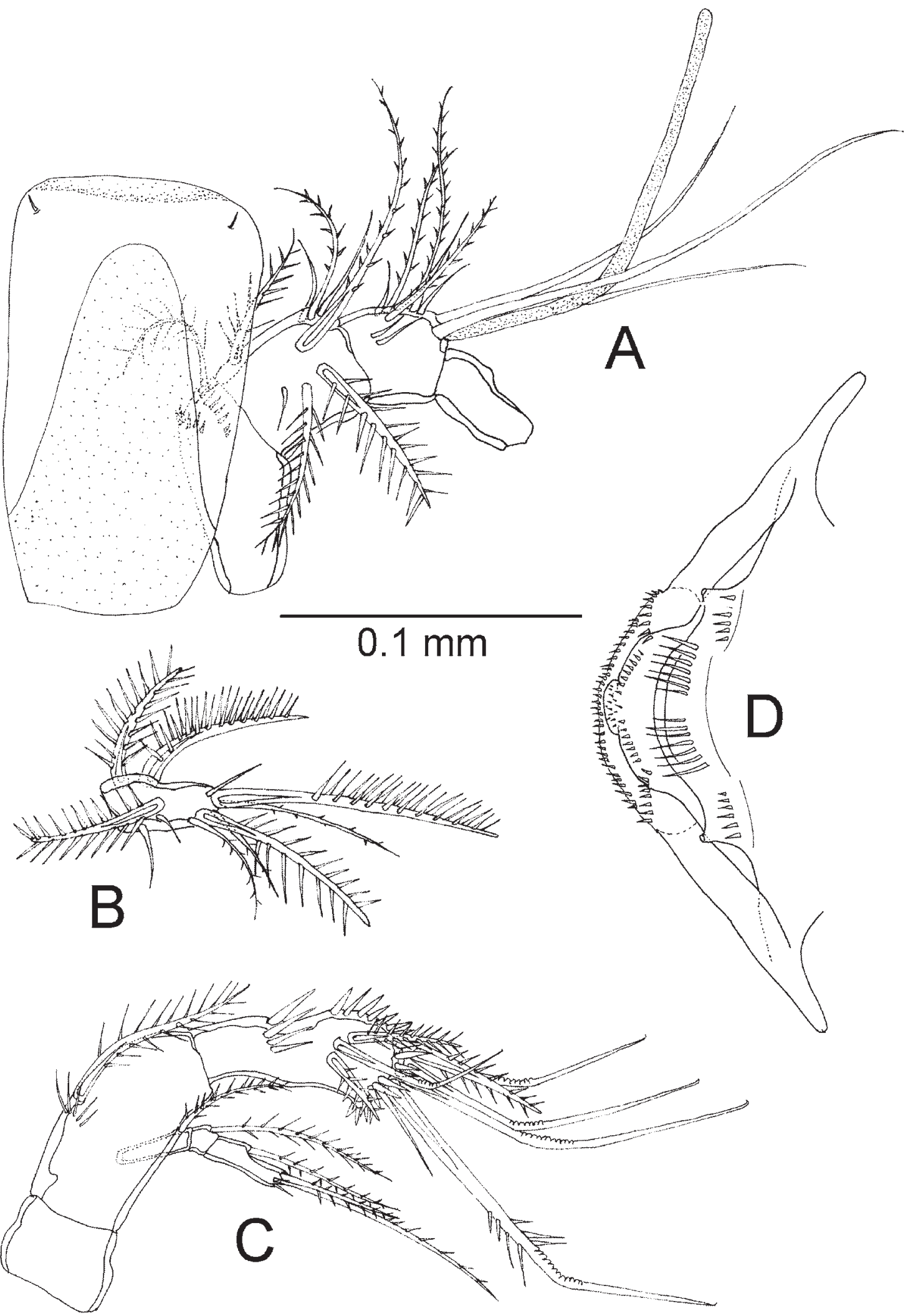

Fig. 11. Danielssenia similis, female. A - rostrum and A1; B - 4th segment of A1; C - A2; D - labrum.

Рис. 11. Danielssenia similis, самка. А - рострум и антеннула; В — 4-й сегмент антеннулы; C — антенна; D - лябрум. 

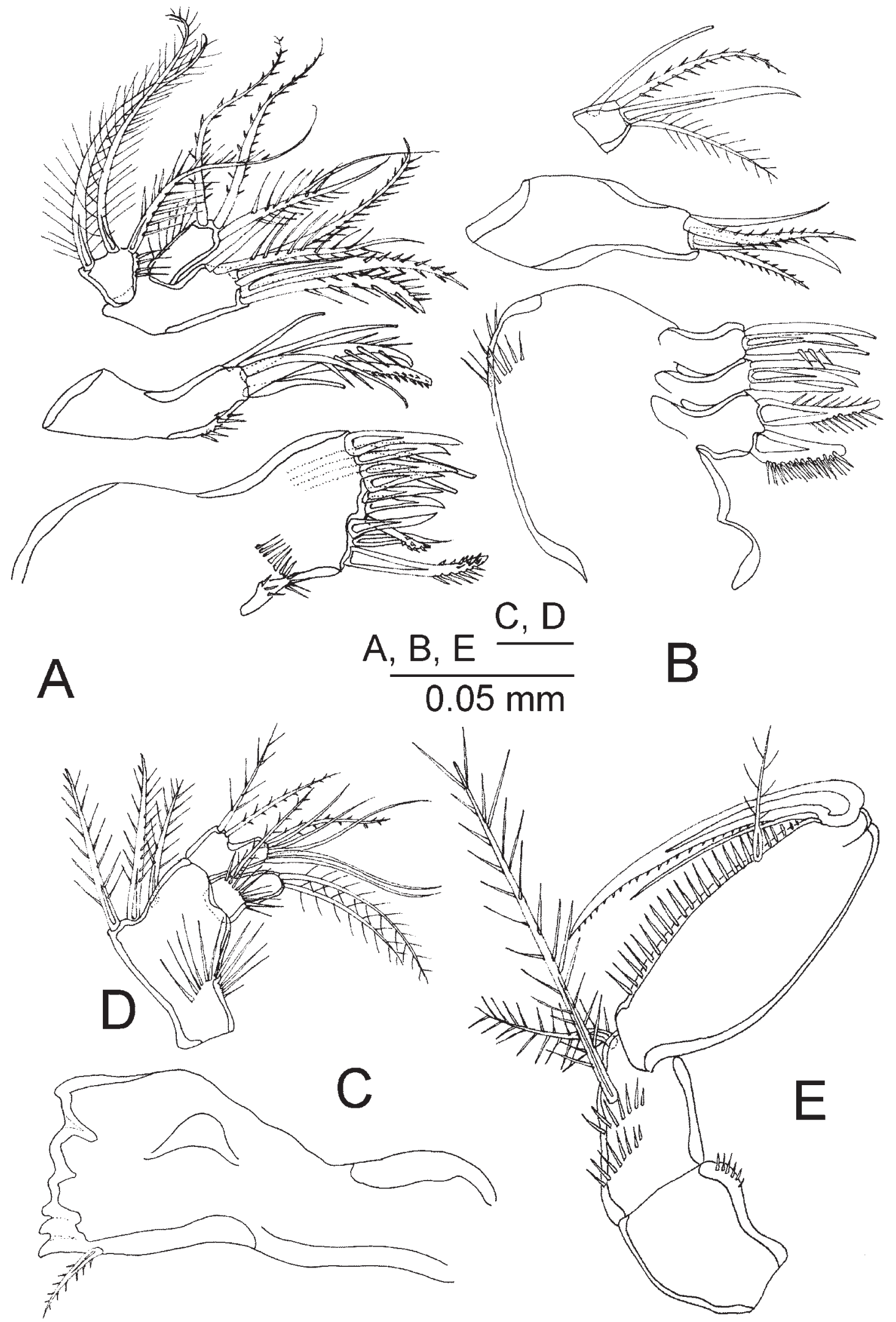

Fig. 12. Danielssenia similis, female. $\mathrm{A}-\mathrm{mxl} ; \mathrm{B}-\mathrm{mx} ; \mathrm{C}-\mathrm{md}$ gnathobase; $\mathrm{D}-\mathrm{md}$ palp; $\mathrm{E}-\mathrm{mxp}$.

Рис. 12. Danielssenia similis, самка. А — максиллула; В — максилла; С — гнатобаза мандибулы; D — пальпа мандибулы; Е — максилипед. 

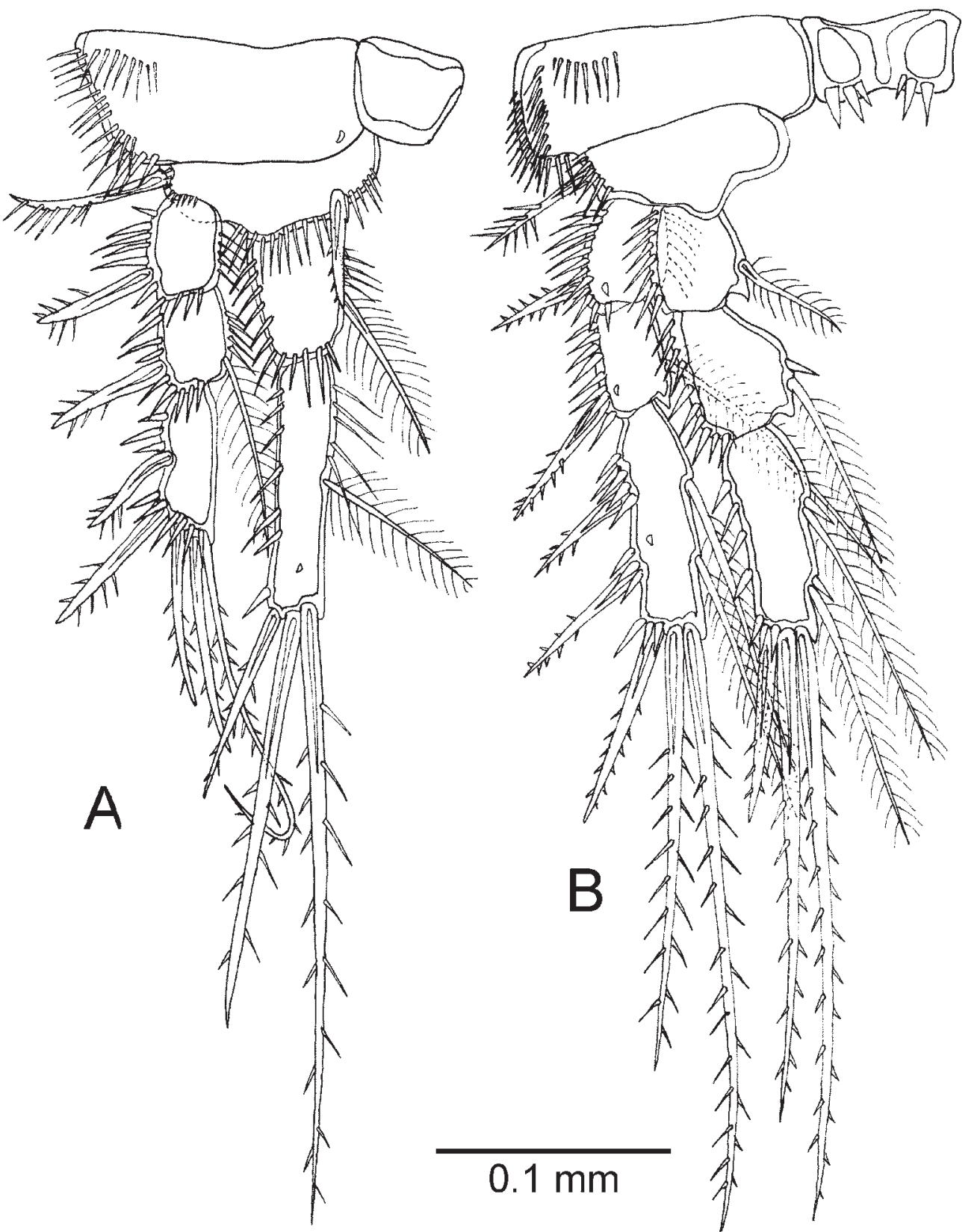


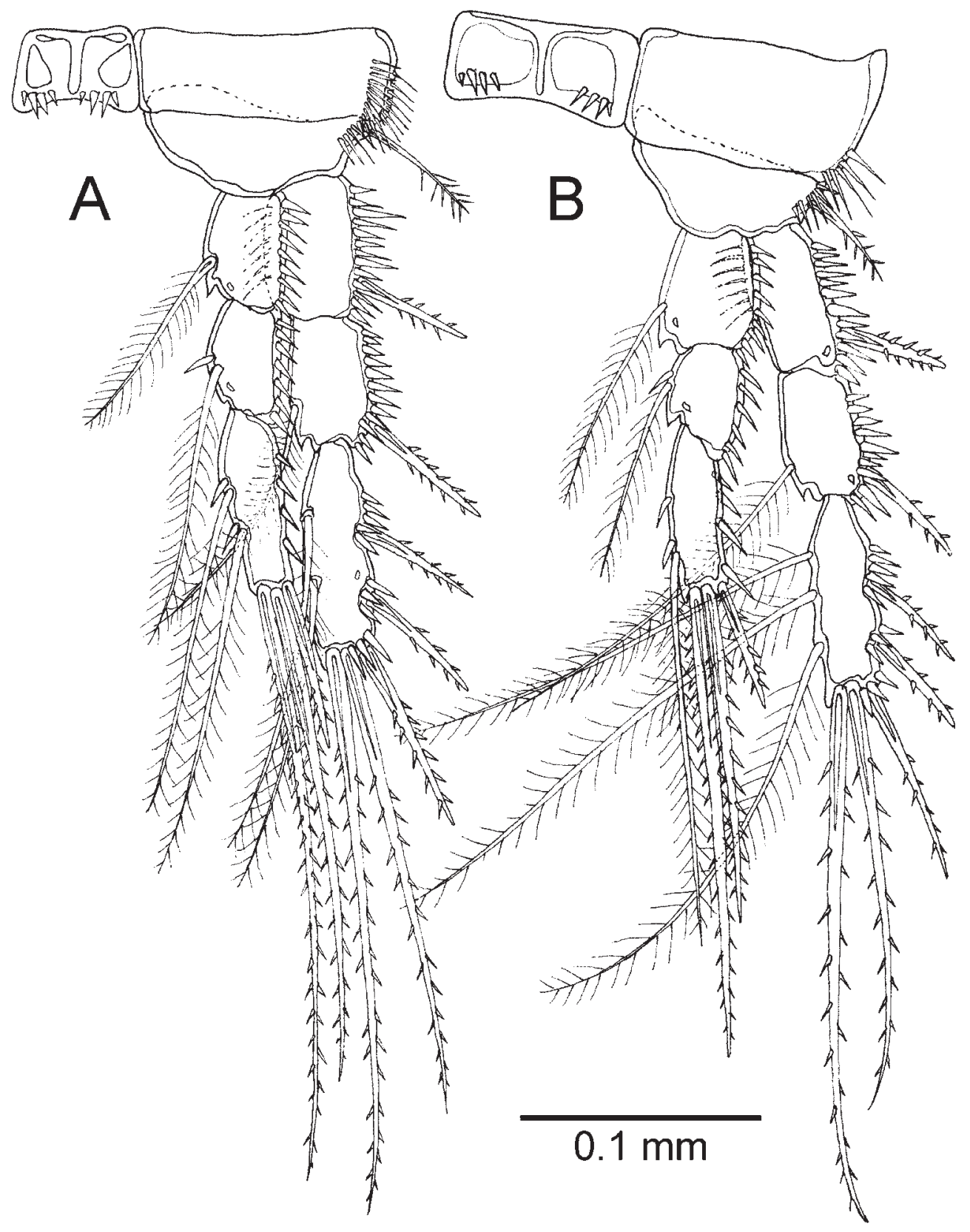

Fig. 14. Danielssenia similis, female. A - P3; B - P4.

Рис. 14. Danielssenia similis, самка. А - 3-я нога; В - 4-я нога.

seta situated medially and one distal smaller plumose seta inserted distally. Basis long with row of long spinules on inner margin and small pinnate seta. Endopodal claw as long as basis with accessory seta near base.

P1 (Fig. 13A). Intercoxal sclerite trapezoid. Coxa with three rows of spinules at distal outer corner. Basis with an outer and an inner spinulose setae and with row of long spinules on distal margin and short at outer distal corner. Exp 3-segmented, each segment with a row of spinules along distal and outer margins; exp-1 with one outer spine, exp-2 with one outer spine and one inner seta, exp-3 with five elements (three outer spines, and two distal setae). Enp 2-segmented, longer than exopodite; enp-2 more than twice as long as enp-1, both segments with rows of spinules along distal, inner and outer margins; enp-1 with an inner seta situated medially, enp-2 with four elements (one inner and two distal setae, and one distal outer spine).

P2 (Fig. 13B). Intercoxal sclerite rectangular with stout spinules on anterior surface. Coxa with three rows of spinules at distal outer corner. Basis with row of outer spinules and an outer spinulose basal seta. Exp 3-segmented, exp-1 and exp-2 with a row of spinules along outer margin, spinules on exp-3 situated patchy around outer spine; exp-1 with one outer spine, exp-2 with one outer spine and one inner seta, exp-3 with seven elements (two inner and two distal setae, and three outer spines). Enp 3-segmented, a little longer than exopodite, each segment with a row of spinules along outer margin; enp-1 and enp-2 each with inner plumose 


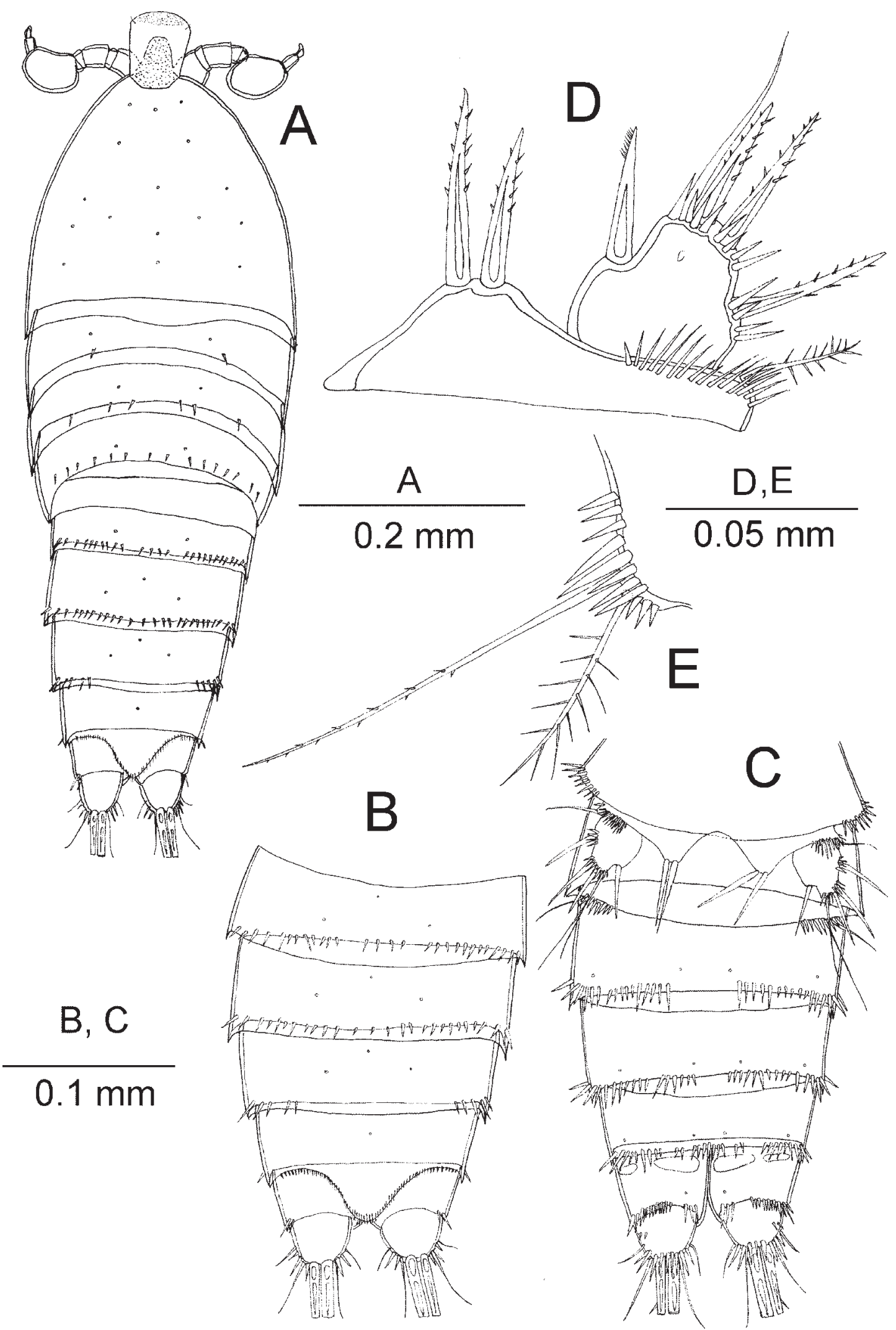

Fig. 15. Danielssenia similis, male. A — body in dorsal view; B — abdomen in dorsal view; $\mathrm{C}$ - abdomen in ventral view; D - P5; E-P6.

Рис. 15. Danielssenia similis, самец. А - туловище, вид сзади; В - абдомен, вид сзади; С - абдомен, вид спереди; D - 5-я нога; Е - 6-я нога. 


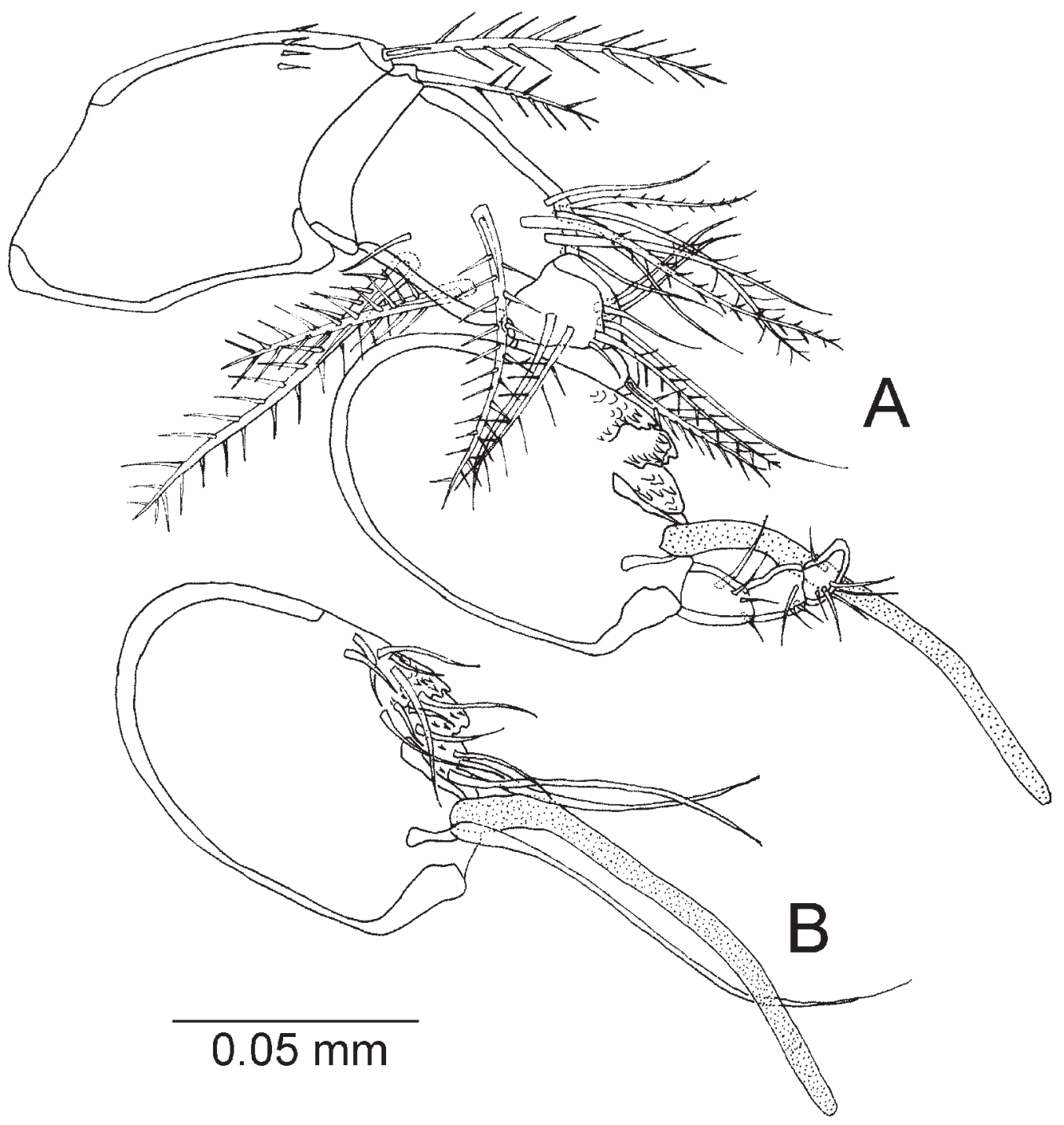

Fig. 16. Danielssenia similis, male. A - A1; B - 6th segment of A1.

Рис. 16. Danielssenia similis, самец. А - антеннула; 6-й сегмент антеннулы.

setae, enp-3 with five elements (two inner and two distal setae, and one outer spine).

P3 (Fig. 14A). Intercoxal sclerite rectangular with stout spinules on anterior surface. Coxa with two rows of spinules at outer margin. Basis with row of outer spinules and an outer spinulose basal seta. Exp 3-segmented, exp-1 and exp2 with a row of spinules along outer margin, spinules on exp-3 situated patchy around outer spines; exp-1 with one outer spine, exp-2 with one outer spine and one inner seta, exp-3 with seven elements (two inner and two distal setae, and three outer spines). Enp 3-segmented, shorter than exopodite. Enp-1 and enp-2 each with row of spinules on outer margin and with one inner plumose seta each, enp-3 with five elements (two inner and two distal setae, and one distal spine).

P4 (Fig. 14B). Intercoxal sclerite rectangular with stout spinules on anterior surface. Coxa with row of spinules at outer corner. Basis with row of outer spinules and an outer spinulose basal seta. Exp and enp 3-segmented, and enp shorter than exp. Exp-1 and exp-2 with a row of spinules along outer border, spinules on exp-3 situated patchy around outer spine; exp-1 with outer spinulose spine, exp-2 with one outer spinulose spine and one inner plumose seta, exp-3 with eight elements (three inner and two distal setae, and three outer spines). Enp-1 and enp-2 each with one inner setae, enp-3 with four elements (one inner and two distal setae, and one outer spine).

Setal formula of swimming legs as follows:

$\begin{array}{lcc} & \text { Exp } & \text { Enp } \\ \text { P1 } & 0: 1: 023 & 1: 121 \\ \text { P2 } & 0: 1: 223 & 1: 1: 221 \\ \text { P3 } & 0: 1: 223 & 1: 1: 221 \\ \text { P4 } & 0: 1: 323 & 1: 1: 121\end{array}$

P5 (Fig. 10F). Benp and exp distinct. Benp with a row of strong spinules around base of outer basal seta and close to joint with exp, with threes patches of spinules on inner and outer margins of endopodal lobe. The latter bears five spinulose setae of which $4^{\text {th }}$ and $5^{\text {th }}$ from outer to inner margin, situated close to each other and farther from the rest. Exp triangular, with five setae: $1^{\text {st }}$ seta ctenoid (one-sidedly plu- 


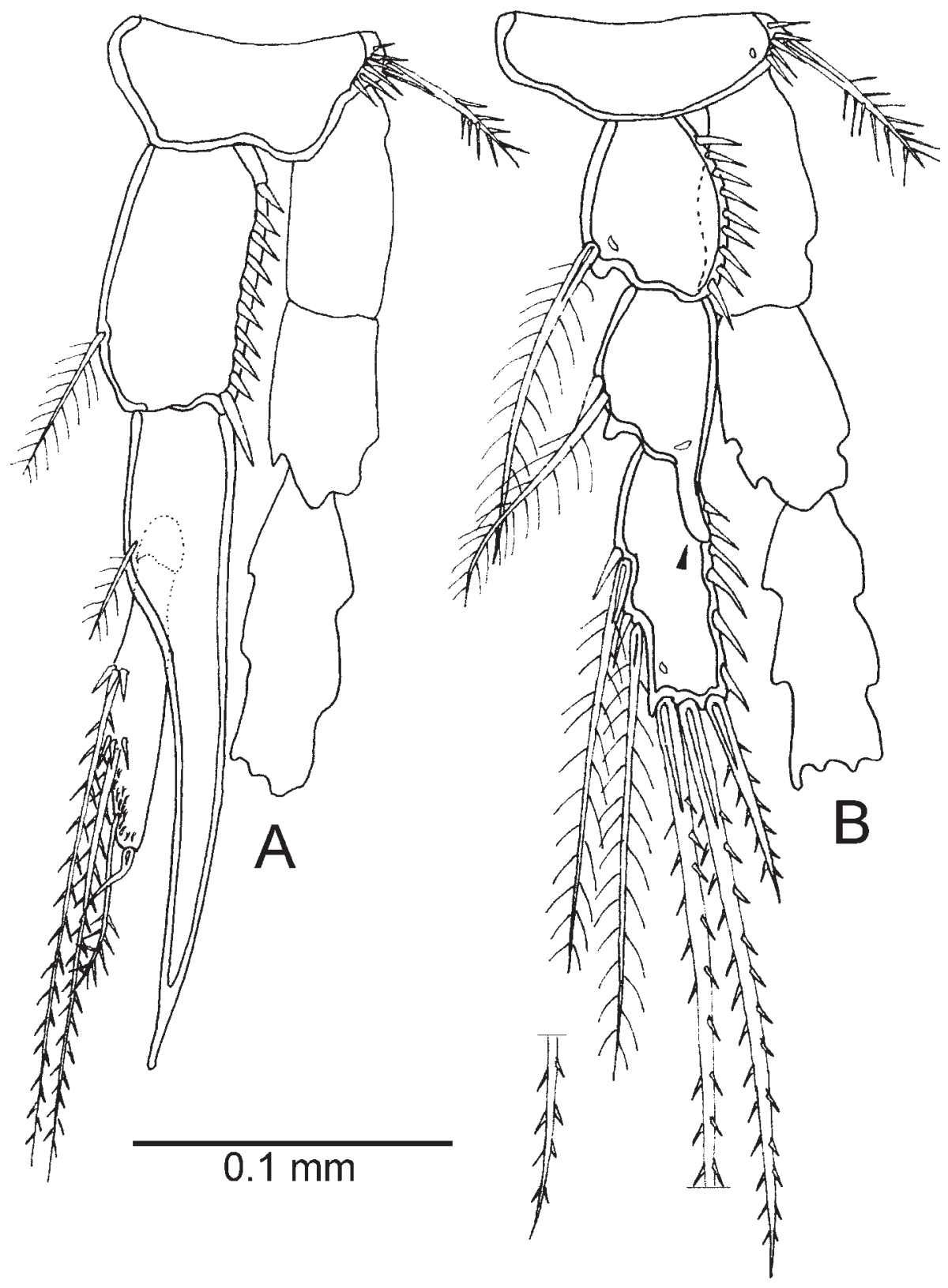

Fig. 17. Danielssenia similis, male. A - P2; B - P3.

Рис. 17. Danielssenia similis, самец. А - 2-я нога; В - 3-я нога.

mose) and $2^{\text {nd }}$ seta from outer to inner margin, smooth and longest, with two rows of spinules at base of outermost and outer subdistal elements.

MALE. Body (Fig. 15A-C). Length from base of rostrum to end of last segment $0.75 \mathrm{~mm}$. Rostrum length 0.09 $\mathrm{mm}$. Body shape and ornamentation as in female. Genital somite and third urosomite not fused. Surface ornamentation as in Fig. $15 \mathrm{~A}-\mathrm{C}$.

A1 (Fig. 16). Subchirocer, 9-segmented. Segment-1 with a row of spinules and a spinulose seta at anterior distal margin. Segment-2 short with one spinulose seta at distal inner corner. Segment-3 with four plumose, two spinulose and five bare setae. Segment-4 with three spinulose and six bare setae. Fifth segment small and bears one spinulose seta at distal margin. Segment-6 (Fig. 16B) expanded and bear- ing aesthetasc fused with bare seta. Last three segments very small forming prehensile claw. Armature formula, 1-(1), 2(1), 3-(11), 4-(9), 5-(1), 6-(13+[1+ae]), 7-(4), 8-(3), 9-(6).

A2, labrum and mouthparts. Not shown as in female.

$P 1$. Not shown as in female.

P2 (Fig. 17A). Exp as in female, enp modified. Enp-1 with row of spinules on outer border and a plumose inner seta. Enp-2 with a mucroniform process at outer distal corner about 3.5 times as long as basal portion of segment and with an inner seta. Enp-3 with patched spinules at the base of two long inner and one shorter inner plumose seta, with short curved spine on distal margin.

P3 (Fig. 17B). As in female, except enp-2 with small recurved process at outer distal corner.

$P 4$. Not shown as in female. 
Table. Distinctive characteristics of D. typica and D. similis (based on Huys \& Gee [1993]). Таблица. Отличительные особенности D. typica и D. similis (на основании Huys \& Gee [1993]).

\begin{tabular}{|l|l|l|}
\hline & \multicolumn{1}{|c|}{ D. typica } & \multicolumn{1}{c|}{ D. similis } \\
\hline Rostrum & $\begin{array}{l}\text { 2 pairs of sensilla [Huys, Gee, 1993, } \\
\text { fig. 14A] }\end{array}$ & $\begin{array}{l}\text { 1 pair of sensilla (present paper, Fig. } \\
\text { 11A) }\end{array}$ \\
\hline $\begin{array}{l}\text { Dorsal frill of P5-bearing } \\
\text { somite }\end{array}$ & $\begin{array}{l}\text { Deeply incised, forming rectangular } \\
\text { lappets [Huys, Gee, 1993, fig. 14A, B] }\end{array}$ & $\begin{array}{l}\text { Rectangular lappets are absent } \\
\text { (present paper, Fig. 10A) }\end{array}$ \\
\hline Maxilliped & $\begin{array}{l}\text { Two-bladed form of syncoxa, one } \\
\text { patch of spinules [Huys, Gee, 1993, } \\
\text { fig. 15E-F] }\end{array}$ & $\begin{array}{l}\text { Syncoxa trapezoid with two rows of } \\
\text { spinules (present paper, Fig. 12E) }\end{array}$ \\
\hline P2 enp-3 male & $\begin{array}{l}\text { Two inner setae long and spiniform, } \\
\text { inner terminal seta reduced, with } \\
\text { spatulate tip; outer terminal seta } \\
\text { represented by small setule; outer spine } \\
\text { curved at tip and standing on } \\
\text { cylindrical process [Huys, Gee, 1993, } \\
\text { fig. 16A-B] }\end{array}$ & $\begin{array}{l}\text { Two inner setae long and plumose, } \\
\text { single terminal seta short and } \\
\text { plumose; outer spine short and } \\
\text { curved (present paper, Fig. 17A) }\end{array}$ \\
\hline Genital field, female & $\begin{array}{l}\text { With minute copulatory pore and } \\
\text { multi-chambered seminal receptacle } \\
\text { [Huys, Gee, 1993, fig. 16E-G] }\end{array}$ & $\begin{array}{l}\text { With comparatively large copulatory } \\
\text { pore and pair-chambered seminal } \\
\text { receptacle (present paper, Fig. 10D) }\end{array}$ \\
\hline P6, male & $\begin{array}{l}\text { 1 plumose seta and 2 minute spiniform } \\
\text { elements [Huys, Gee, 1993, fig. 16E] }\end{array}$ & $\begin{array}{l}\text { 1 plumose seta and 1 spinule } \\
\text { (present paper, Fig. 10D) }\end{array}$ \\
\hline
\end{tabular}

P5 (Fig. 15D). Exp and benp separate. Benp with row of spinules close to joint with exp, and with plumose outer basal seta. Endopodal lobe reduced, bearing two setae of different lengths. Exp with two rows of strong spinules distally and on upper and outer margin and with five setae, inner seta ctenoid, one-sidedly plumose (inner and outer setae located medially on inner and outer margin, and separated from distal armature by the wide gap).

P6 (Fig. 15E). A single plate fused to somite bearing two setae and several strong spinules on each side.

REMARKS. This species had been described by Chislenko [1978] from the Posyet Gulf (the Sea of Japan). Since that, it was mentioned only once. Zavarzin and Atamanova [2014] reported it from the shallow-water zooplankton of coastal waters of southern Sakhalin, the Sea of Okhotsk; but neither morphological description no drawing was provided.

Chislenko [1978] noted the close similarity between $D$. similis and D. typica, but distinguished it from D. typica on the basis of the following characters: i) larger size of both sexes (female - $0.96 \mathrm{~mm}$ for, male - $0.89 \mathrm{~mm}$; ii) a mxp with only 1 seta on the syncoxa and a somewhat longer seta on the basis; iii) the sexual dimorphism on P2 enp, with some distinctive features in males; iv) structure of the female' genital field; v) setation of P5 (in both sexes); vi) setation of CR. In their revision of Danielssenia, Huys \& Gee [1993] reasoned against the first three characters but did not commented on the last three. They suggested that $D$. similis is most likely referable to $D$. typica, but being not able to examine the type or topotype material they regarded the species as a species inquirenda.

Comparative analysis of the type material and new material from the Sea of Okhotsk, the D. typica specimens from the White and Kara seas and previous descriptions yields the following results (briefly summarized in the Table):

1) Size: $D$. similis specimens were consistently larger than those of D. typica from the White and Kara seas. We, however, agree with Huys \& Gee [1993] in that this charac- ter is of no particular significance as it the size of $D$. similis lies within (but near the upper limit of) the wide and geographically variable size range of $D$. typica.

2) Maxilliped: there are two plumose setae on the basis (one long situated medially, and one smaller element subdistantly, the latter absent on Chislenko's [1978: 162, fig. 1.4]) drawing, as in to D. typica. However, the two species differ in the form of the syncoxa $(D$. similis - trapezoid, D. typica - two-bladed) and arrangement of the spinules (see Table).

3) Sexual dimorphism on P2 enp:

- the inner seta on the male enp-1, is missing on Chislenko's [1978: 164, fig. 3.4] drawing: this seta is actually present in both sexes (see the Fig. 17A);

- the male enp-3: Chislenko [1978: 164, figure 3.4] drew two long inner setae, one shorter and broad terminal seta, and short curved spine on terminal position on this segment, and directly indicated 4 appendages in his description. Huys and Gee [1993] believed the reduction in the number of setae on enp-3 to be "highly improbable" and assumed that Chislenko had combined two fine terminal setae and drawn them as the broad one. However, careful inspection of our specimens confirms the presence of only 3 plumose setae on the enp-3. Thus, this character distinguishes it from all other congeners except $D$. reducta, whose males also show reduced setation of this segment [Gee, 1988].

4) Genital field: $D$. similis differs from $D$. typica in size of the copulatory pore and structure of seminal receptacle (Table).

These two species also differ in the number of sensillae on the rostrum, shape of the of P5-bearing somite, in setation of male P5 benp, male P6 and CR (Table). We believe that the identity of our specimens to the type material and original Chislenko's [1978] description, coupled with the differences from other Danielssenia species, are sufficient to assign our specimens to $D$. similis and to remit its species inquirenda status. 
ECOLOGY AND DISTRIBUTION. Chislenko [1978] found his specimens of $D$. similis in silty sand at depth of 3$4 \mathrm{~m}$ at the Posyet Gulf (Sea of Japan). Our specimens were found in considerable abundance in water samples collected in the Prostor Bay, the South Kuril Islands (Sea of Okhotsk), at a distance of $1300 \mathrm{~km}$ eastward from the type locality. The specimens from the southern Sakhalin, collected by Zavarzin \& Atamanova [2014], have been also examined and doubtlessly belong to the same species. Thus, the known geographical range of this species includes coastal waters of the northwestern Pacific.

\section{Discussion}

In a series of papers by Huys \& Gee [1993, 1996] and Gee \& Huys [1994] suggested that sexual dimorphism of the swimming legs is the key to understanding the phylogenetic relationships within the "danielsseniid" group of genera. In particular, the reduction or loss of setae on exp-1 of P2-P4 and enp-2 of P2, as well as differences between sexes in the number of elements on the enpodites of P3 and P4, were considered as an important feature of Danielssenia. Noteworthy, the distal transformations in the male P2 endopodite, with reduction of the terminal setae on enp-3 are in line with the generic peculiarities.

The genus Danieissenia now contains six well defined species: D. typica Boeck, 1873 (type species), D. quadriseta Gee, 1988, D. reducta Gee, 1988, D. similis Chislenko, 1978, stat.n., D. spiridonovi sp.n., and D. spitsbergensis Gee et Huys, 1994 (incertae sedis in Danielssenia). Some of these species have features not fully corresponding to the generic diagnosis given in Huys et al. [1996]. To accommodate them, we propose the amended diagnosis below.

AMENDED DIAGNOSIS of the genus Danielssenia Boeck, 1872 (Danielsseniidae). Body. Variable in size (0.4$1.0 \mathrm{~mm}$ ), slightly fusiform and dorsoventrally flattened; dorsal hyaline frill on P5-bearing somite deeply incised. Rostrum large, hyaline, typically deflexed with two pairs of sensilla. Vestigial P6 of female genital double-somite with one seta; seminal receptacle with paired, anteriorly directed chambers extending to anterior margin of somite. CR parallel. A1. 4-segmented with numerous pinnate setae in female. 7-9- segmented, subchirocer, segment-5 or segment-6 very swollen in male. A2. With allobasis and antennary exp 3segmented, exp-1 with one seta. $M d$. Coxa with short, bluntly rounded teeth on gnathobase. Basis with three setae. Rami 1 -segmented, equal in length. $M x l$. With three tubular setae, one pinnate seta and one spine on coxal endite. Basal endite with four setae and one spine. $M x$. With tubular setae on coxal endites, allobasis and endopod. Mxp. Syncoxa with two setae. Basis with a very small pinnate seta on palmar margin. P1. Exp-3 distal outer spine longer than middle outer spine. Enp-2 longer than enp-1, inner seta implanted medially. P2-P4. Rami 3-segmented; exp-1 without inner seta. Male P2 enp-2 apophysis reaching or extending beyond margin of enp-3 on which has a distal outer spine, reduced distal and outer setae and terminal setae reduced or one of these absent, inner setae enlarged compared to female. P5. In female, exp and benp separate, limbs not fused medially; endopodal lobe with three or five setae; exp with four or five setae. In male, limbs fused medially, endopodal lobe with two setae, which differ in length. Male P6. With two setae.

DISTRIBUTION. Representatives have been reported from upper shelf of North Atlantic (including North, Baltic,
Norwegian Seas), all Arctic seas, North Pacific (eastern coast - Gulf of Alaska, Vancouver, Seattle; western - Sea of Okhotsk, Japan and Yellow seas). Not recorded in tropical zone or in the Southern Hemisphere. Arcto-boreal circumpolar shallow-water genus.

\section{KeY to SPECIES OF DANIELSSENIA:}

1. P2-P3 exp-3 with 2 inner setae, P4 exp-3 with 3 inner

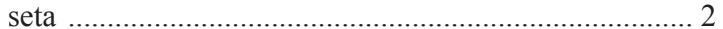

- P2-P3 exp-3 with 1 inner setae, P4 exp-3 with 1 or 2 inner setae .................................................................. 5

2. P2-P3 enp-3 with 2 inner setae, P4 enp-3 with 1 inner setae ............................................................. 3

- P2 enp-3 with 2 inner setae, P3-P4 enp-3 with 1 inner

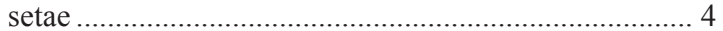

3. Mxp syncoxa trapezoid with two rows of spinules. D. similis

- Mxp different * D. typical

4. P3-P4 exp-3 with 3 outer spines ................ D. quadriseta

- P3-P4 exp-3 with 2 outer spines ........... D. spitsbergensis 5. P4 exp-3 with 1 inner seta ................ . spiridonovi sp.n. - P4 exp-3 with 2 inner setae ........................... D. reducta

Acknowledgements. The authors thank colleagues from the P.P. Shirshov Institute Oceanology, Russian Academy of Science, the Korea Polar Research Institute (2019 KoreaRussia International Arctic Marine Geoscience Expedition on Icebreaker Research Vessel "Araon") and Russian Federal Research Institute of Fisheries and Oceanography, for help in collecting material during research cruises. The authors thank to E.L. Markhaseva for sending us the D. similis type material. We also thank two anonymous reviewers for their careful reading of our manuscript and their insightful comments and suggestions. Financial support was provided by the Russian Foundation for Basic Research (grants number 19-05-00128 and 18-05-60228) and The Korea Polar Research Institute (KOPRI) Grant PM19050 (KIMST Grant 2016247). This research was performed according to the Development program of the Interdisciplinary Scientific and Educational School of M.V. Lomonosov Moscow State University "The future of the planet and global environmental change".

\section{References}

Boeck A. 1873. Nye Slægter og Arter af Saltvands-Copepoder // Forhandlinger i Videnskabsselskabet i Kristiania 1872. P.3560.

Chislenko L.L. 1978. [New species of harpacticoid copepods (Copepoda, Harpacticoida) from Posyet Bay of the Japan Sea] // Medvedev G.S. (ed.). Novye vidy zhivotnykh. Trudy Zoologicheskogo Instituta AN SSSR. Vol.61. P.161-192 [in Russian].

Garlitska L.A., Azovsky A.I. 2016. Benthic harpacticoid copepods of the Yenisei Gulf and the adjacent shallow waters of the Kara Sea // Journal of natural History. Vol.50. No.47-48. P.29412959. https://doi.org/10.1080/00222933.2016.1219410

Gee J.M. 1988. Taxonomic studies on Danielssenia (Crustacea, Copepoda, Harpacticoida) with descriptions of two new species from Norway and Alaska // Zoologica Scripta. Vol.17. No.1. P.39-53. https://doi.org/10.1111/j.1463-6409.1988. tb00085.x Table. 
Gee J.M., Huys R. 1990. The rediscovery of Danielssenia intermedia Wells 1965 (Copepoda, Harpacticoida): a missing link between the "danielsseniid" genera and Paranannopus Lang 1936 (Paranannopidae) // Journal of Natural History. Vol.24. No.6. P.1549-1571. https://doi.org/10.1080/00222939000770891

Gee J.M., Huys R. 1991. A review of Paranannopidae (Copepoda: Harpaclicoida) wilh claviform aeslhetascs on oral appendages // Journal of Natural History. Vol.25. No.5. P.1135-1169. https://doi.org/10.1080/00222939100770741

Gee J.M., Huys R. 1994. Paranannopidae (Copepoda: Harpacticoida) from sublittoral soft sediments in Spitzbergen // Journal of Natural History. Vol.28. No.1. P.1007-1046. https://doi.org/ $10.1080 / 00222939400770541$

Huys R., Boxshall G.A. 1991. Copepod Evolution. London: The Ray Society Publ. 468 p.

Huys R., Gee J.M. 1992. A revision of Danielssenia perezi Monard, D. paraperezi Soyer, D. eastwardae Coull (Harpacticoida; Paranannopidae) and their transfer to a new genus // Zoological Journal of the Linnean Society. Vol.104. P.31-56. https:// doi.org/10.1111/j.1096-3642.1992.tb00913.x

Huys R., Gee J.M. 1993. A revision of Danielssenia Boeck and Psammis Sars with the establishment of two new genera Archisenia and Bathypsammis (Harpacticoida: Paranannopidae) // Bulletin of the Natural History Museum, London (Zoology). Vol.59. No.1. P.45-81.

Huys R., Gee J.M. 1996. Sentiropsis, Peltisenia and Afrosenia: three New Genera of Paranannopidae (Copepoda, Harpacticoida) // Cahiers de Biologie Marine. Vol.37. No.1. P.49-75.
Huys R., Gee J.M., Moore C.G., Hamond R. 1996. Marine and brackish water harpacticoids, Part $1 / /$ Synopses of the British Fauna (new series) No.51. Shrewsbury: Field Studies Council. $352 \mathrm{p}$.

Lang K. 1936. Copepoda Harpacticoida // Further zoological Results of the Swedish Antarctic Expedition 1901-1903 under the Direction of Dr Otto Nordenskjöld. Vol.3. No.3. P.1-68.

Sars G.O. 1911. An account of the Crustacea of Norway, with short descriptions and figures of all the species. Vol.5. Copepoda Harpacticoida. Bergen: Bergen Museum.

Walter T.C.; Boxshall G. 2021. World of Copepods Database. Danielssenia Boeck, 1873. Accessed through: World Register of Marine Species at: http://marinespecies.org/aphia. php?p= taxdetails\&id $=115287$ on $2021-02-23$

Wells J.B.J. 2007. An annotated checklist and keys to the species of Copepoda Harpacticoida (Crustacea) // Zootaxa. Vol.1568. P.1-872. https://doi.org/10.11646/zootaxa.1568.1.1

Willen E. 2000. Phylogeny of the Thalestridimorpha Lang, 1944 (Crustacea, Copepoda). Göttingen: Cuvillier Verlag. 246 p.

Zavarzin D.S., Atamanova I.A. 2014. [Màtå zooplankton seasonal dynamics in Ptichye Lake and adjoining sea coastal waters of southern Sakhalin] // Chteniya pamyati Vladimira Yakovlevicha Levanidova. Vladivostok. Vyp.6. P.239-249 [in Russian].

Responsible editor I.N. Marin 